\title{
Antibacterial Activity of Thiazole and its Derivatives: A Review
}

\author{
Patitapaban Mohanty ${ }^{1}$, Sunita Behera ${ }^{1}$, Rubi Behura ${ }^{1}$, Lipsa Shubhadarshinee ${ }^{1}$, \\ Priyaranjan Mohapatra ${ }^{1}$, Aruna Kumar Barick ${ }^{1}$, Bigyan Ranjan Jali 1,* (D) \\ 1 Department of Chemistry, Veer Surendra Sai University of Technology, Burla, Sambalpur-768018, Odisha, India \\ * Correspondence: bigyan.Jali7@gmail.com
}

Received: 15.04.2021; Revised: 20.05.2021; Accepted: 25.05.2021; Published: 18.06.2021

\begin{abstract}
Thiazoles are one of the most intensively scrutinized classes of 5-membered aromatic heterocycles. Many natural and synthesized thiazole and its derivatives showed significant biological activity. Due to its unique properties, thiazole derivatives show significant antibacterial activity against various bacteria and pathogens. Thus, the present review ascribes the antibacterial activity of various thiazole and its derivatives. From using various databases, all the relevant literature has been reviewed. The review was deliberated based on the significant papers on the antibacterial activity of thiazole derivatives. Thiazole and its derivatives, a significant class of heterocyclic derivatives, have played an important role in chemical sciences. Due to their unique properties, they play an important role in the pharmaceutical industry. Thiazole and its derivatives show significant anticancer, anti-tuberculous, antioxidant, and anti-inflammatory activities. Due to their tremendous biological significance, scientists are actively engaged in designing new biological active thiazole derivatives. This review emphasized the antibacterial properties of various thiazole and its derivatives. The present study will help researchers design and synthesize various biological active molecular probes and study their antibacterial properties using various processes against various bacteria and pathogens.
\end{abstract}

Keywords: thiazole; antibacterial; bacteria; pathogen.

(C) 2021 by the authors. This article is an open-access article distributed under the terms and conditions of the Creative Commons Attribution (CC BY) license (https://creativecommons.org/licenses/by/4.0/).

\section{Introduction}

In the clinical world, consideration of retardation of pathogenic bacteria towards the available antibiotic was becoming a major worldwide problem as many bacterial pathogens have already established resistance against them [1-6]. Therefore, there could be the appearance of increasing in the mortality rate for gram-positive and/or gram-negative bacterial diseases. It is mainly due to the over-growth in population and extreme modernization for comfort. Hence, the rapid development of microbial resistance leads to discovering a new effective antimicrobial drug agent, which can reduce the bacterial mortality rate [7-12]. To set up a revolutionary change in the failure of synthesizing selective antibacterial drugs, researchers have been endeavored by a lot of eminent expertise from last few decades. To achieve a new effective scaffold for an efficient fight against bacterial viruses is required. The research on the development of new antimicrobial agents has mainly focused on two aspects like increasing potent bacterial antigen drugs and the appearance of new bacteria pathogen. The main aspect of synthesizing effective drugs is their structural characteristic and the rate of activity. Initially, there has been consideration of a heterocyclic compound as a parent https://biointerfaceresearch.com/ 
compound to synthesize the effective antibacterial drug. The assessment of those vast antimicrobial literature data admits that heterocyclic compound has played a vital role in the clinical field [13-18]. Therefore, in the field of pharmacology, heterocycles are very popular for their unique controlling properties within a drug, such as a solubility, lipophilicity, and polarity, and are also being investigated several times for the discovery of desired active drugs [19-21].

The fascinating biological significance of antibacterial pathogens has led to the urgency for drug discovery and the synthesis of new antimicrobial compounds. Thiazoles are one of the most intensively scrutinized classes of 5-membered aromatic heterocycles. Large extent research on thiazole ring from the past two to three decades has proven that the thiazole scaffold has various active biological properties such as antioxidant, antibacterial, anti-viral, diuretic, antitumor and anti-convulsing properties [2223]. Thiazole has an electron-donating group (-S) and an electron-accepting group (-N-). The aromaticity of thiazole was only due to the delocalization of a non-bonding pair of electrons from the sulfur atom to fulfill the vacant $6 \mathrm{p}$ electrons to fulfill Hackle's rule (Scheme-1).

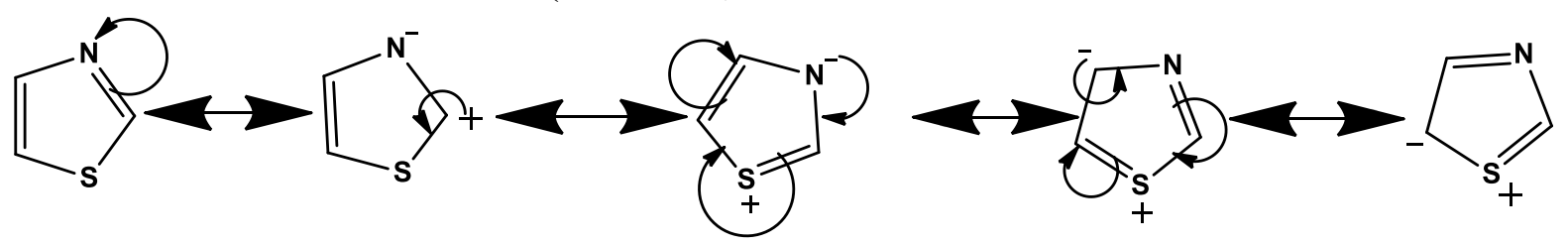

Scheme 1. Resonating structure of thiazole.

Divergent moderation of the thiazole ring at various positions led to various novel compounds with a wide spectrum of biological activities. Due to biological activity and availability in nature, heterocyclic thiazole compound plays a vital role in the clinical field to treat various bacterial infections in the human body [2425]. This type of biological investigation takes us to a new world of research to synthesize newly novel derivatives with strong biological activity. The past few years have proved a remarkable decrease in the mortality rate caused by a bacterial disease. The urgency of detecting the active pathogenic bacterial resistance creates a new researched field of synthesizing the novel thiazole derivatives as a potent antibacterial agent. The thiazole nucleus is an active nucleus as thiazole-containing compounds offer a wide range of applications as pharmacological agents. Hantzsch and weber first described it in 1887. Antibiotic such as Penicillin (5), Ceftriaxone (3), Ampicillin (1), Cefotaxime (4), Amoxicillin (2), antimicrobials such as Myxothiazole (10), sulfathiazole (6), Ethaboxam (8), Abafungin (7), Ravuconazole (9) and have thiazole nucleus (Figure 1). Thiazole is mostly found in vitamins [26-28]. The most important naturally occurring thiazole derivative is thiamine (vitamin B1). Various natural food flavors and aroma consisting of thiazole nucleus. The literature review recommended that thiazole derivatives have fascinated the interest of chemists in the field of drugs and pharmaceuticals [29-31]. All this information was active strength to grow new thiazole derivatives with a broad structural variation. Hence, this present review recaps the effect of various substituents in thiazole heterocyclic rings to develop novel thiazole derivatives for antibacterial potential in different cell lines by analyzing the structure-activity relationship and mechanism of action of a wide range of derivatives. 


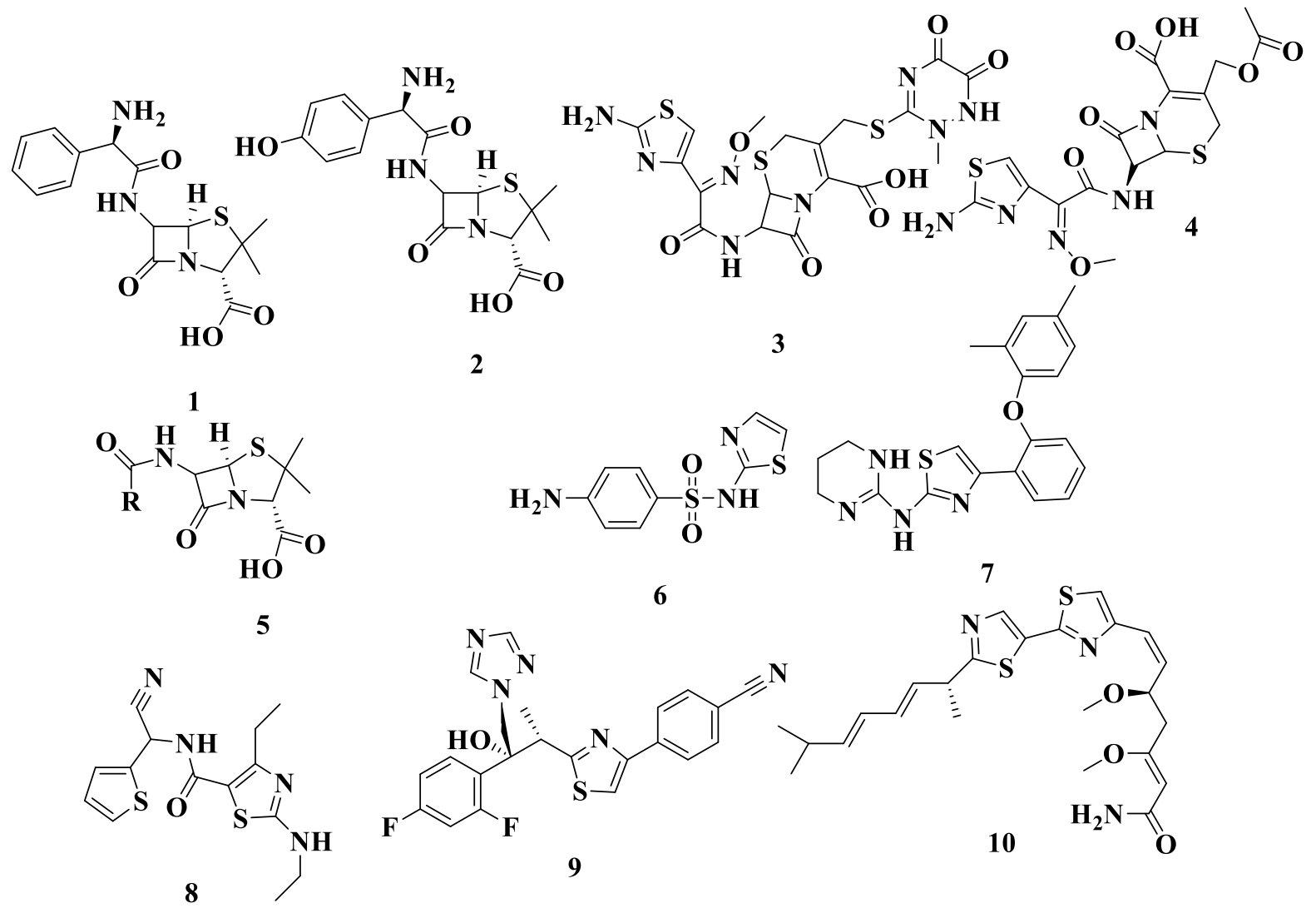

Figure 1. Various antibiotics having an active thiazole nucleus.

\section{Results and Discussions}

Thiazole and its derivatives show potent antimicrobial activity against various bacteria and pathogens. In this regard, Bobade et al. reported a series of thiazole derivatives and examined their antibacterial activity against various bacteria (Figure 2). The microbial study found that 11a-11c ascribe excellent and prominent antibacterial activity against the fungus bacteria [32]. A series of novel 2-(3,5-diphenyl-4,5-dihydro-1H-pyrazol-1-yl)-4phenylthiazoles (12a-i) was demonstrated by Sharifzadeh et al. and investigated the antibacterial activity against gram-positive and negative bacteria. From the antibacterial data, it is found that 12a-d showed moderate activity against Escherichia coli. However, 12e-i showed moderate activity against Staphylococcus Aurous bacteria [33]. A series of acetamide substituted thiazole derivatives (13a-e) was reported by Pawar et al. All the derivatives displayed potent microbial activity against Escherichia coli, Staphylococcus aureus, and Bacillus subtilis by using the broth dilution method [34]. Nural et al. reported a series of methyl 5,5-diphenyl-1-(thiazol-2-yl)pyrrolidine-2-carboxylate derivatives (14a-j) and studied their biological activity against different bacterial and fungal strains and $M$. tuberculosis H37Rv strain. The authors found that $14 \mathrm{a}-\mathrm{j}$ exhibited persuasive antibacterial activity as compared to the reference drug molecules [35]. A bunch of 2,3,4,6-tetra-O-acetyl- $\alpha$-D-glucopyrranosyl derivatives (15a-f) was reported by Metwali et al. The antibacterial activities were demonstrated against various bacteria. The microbial study confirmed that all the compounds exhibited considerable inhabitation against Escherichia coli and Staphylococcus aureus bacteria using the agar dilution method [36]. Pyrazole-based thiazole derivatives play an important role in the pharmaceutical field. In this context, a series of thiazole derivatives (16ai) reported by Desai et al. The authors suggested that 16a-i displayed potent activity against 
various bacteria compared to that of reference drug Ampicillin. The presence of an electronwithdrawing group on the benzene ring enhanced the antibacterial activities of these derivatives [37]. Similarly, derivatives (17a-g) were employed to detect the antibacterial activity against gram-positive and negative bacteria using the broth dilution method. From the experimental data, it is found that all the synthesized derivatives show prominent antibacterial activity against Staphylococcus aureus, Staphylococcus pyogenic, Escherichia coli, and Pseudomonas aeruginosa [38].

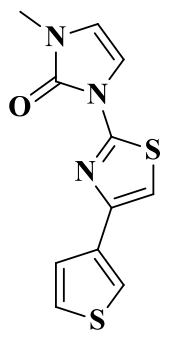

$11 \mathbf{a}$<smiles>CCn1ccn(-c2nc(-c3ccsc3)cs2)c1=O</smiles>

$11 b$<smiles>CCn1ccn(-c2nc3c(s2)C(C)Sc2sccc2-3)c1=O</smiles>

$11 \mathrm{c}$<smiles>N=C1c2ccccc2CC[C@H]1c1ccc(Cl)cc1</smiles>

$12 \mathrm{a}$

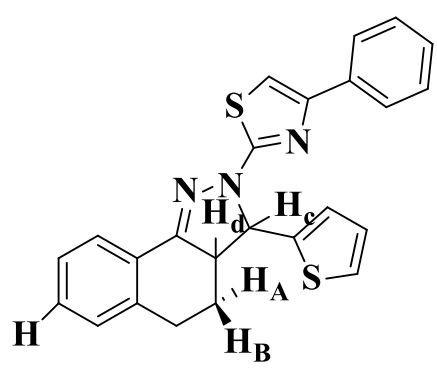

$12 \mathrm{~b}$<smiles>[2H]C1(c2ccc(OC)cc2)[C@@H]([CH2])C(c2ccc(OC)cc2)=NN1c1nc(-c2ccccc2)cs1</smiles>

$12 \mathrm{c}$<smiles>Cc1ccc(C2=N[C@H](c3ccc(-c4ccccc4)cn3)[C@H](C)[C@H]2c2ccc(C)cc2)cc1</smiles>

$12 d$

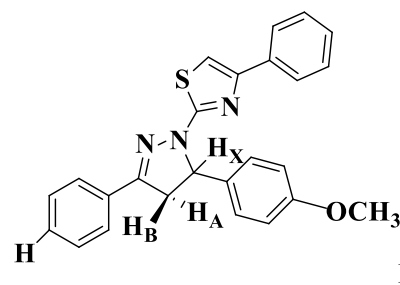

$12 \mathrm{~g}$

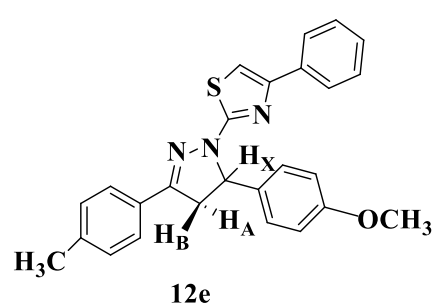

$12 \mathrm{e}$

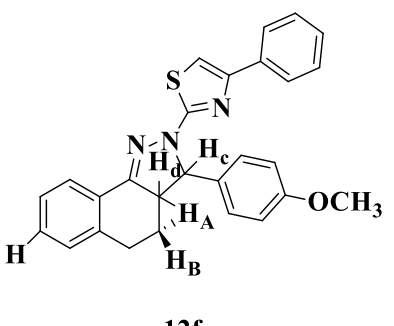

$12 \mathrm{f}$

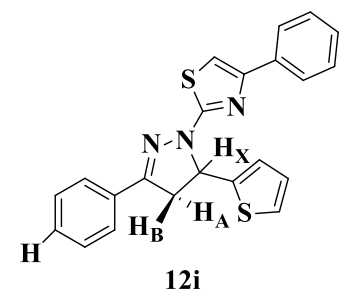

$12 \mathrm{~h}$
$12 \mathrm{i}$ 


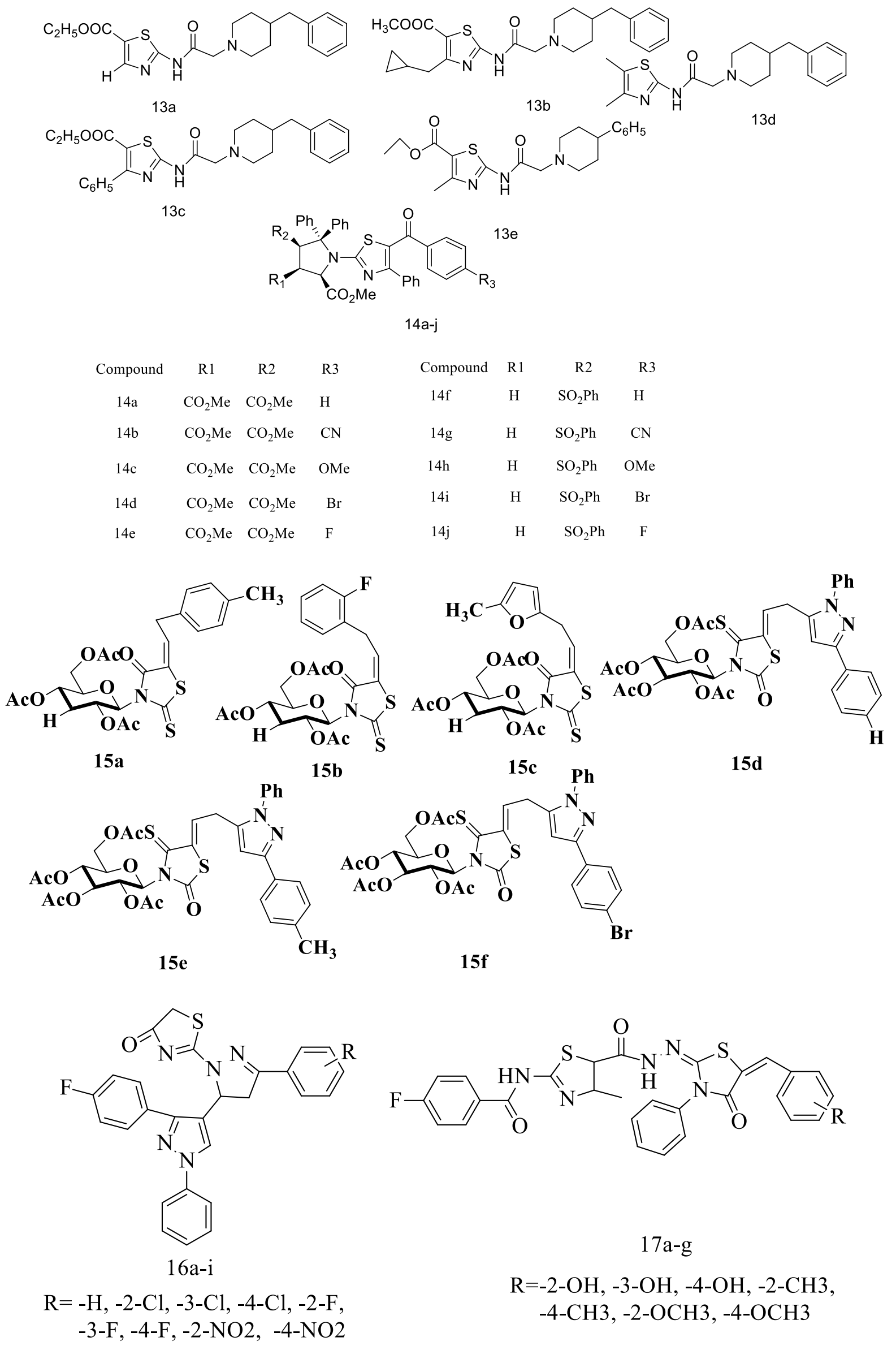

Figure 2. Various thiazole derivatives with antibacterial activities against various bacteria. 
The antibacterial activities of 1,2,4-triazoles and 1,3,4-thiadiazoles bearing imidazole[2,1-b]thiazole derivatives (18-19) were screened against various pathogen and bacteria by using the micro broth dilution method. It revealed that all the derivatives have potent antibacterial activity against $S$. aureus, E. coli, T. tonsurans, and T. mentagrophytesvar [39]. Gouda et al. reported a series of thiazole and pyrazole derivatives (20-21) and examined the antibacterial activity against various bacteria. All the synthesized derivatives showed better antibacterial activity than the reference drug molecules [40]. The thiazole derivatives (22a-b) were used for the antibacterial activity against gram-positive and negative bacteriausing the disc diffusion method. The authors suggested that $22 \mathrm{a}-\mathrm{b}$ show better activity as compare to reference drug molecule [41].<smiles></smiles><smiles>CNc1nnc(Cc2csc3nc(-c4ccc(Br)cc4)cn23)s1</smiles><smiles>CNc1nnc(Cc2csc3nc(-c4ccc(Br)cc4)cn23)s1</smiles><smiles>N#CC(C(=O)Nc1sc2c(c1C(N)=O)CCCC2)=C1SC(=O)CN1P</smiles><smiles>Nc1nc(-c2cc(Cl)sc2Cl)cs1</smiles>

22a 22b<smiles>Cc1ccc(N/N=C2/NC(=O)S/C2=C(\C#N)C(=O)Nc2sc3c(c2C(N)=O)CCCC3)cc1</smiles>

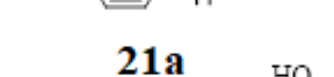

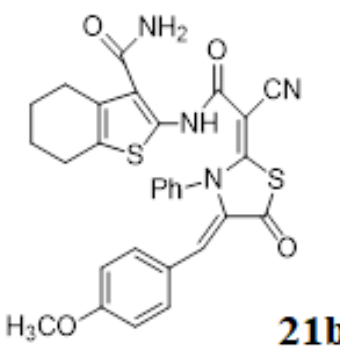

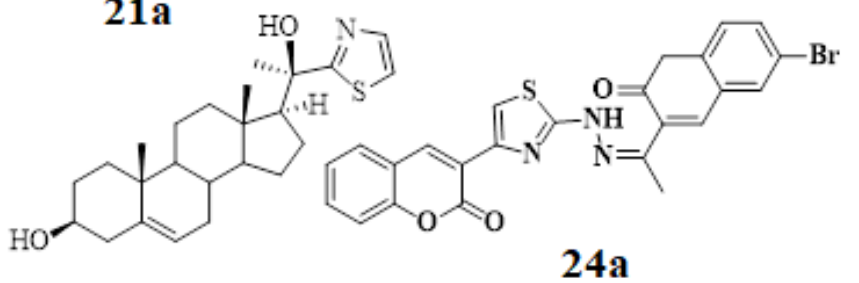

23<smiles>O=c1oc2ccccc2cc1-c1csc(N/N=C\c2ccccc2O)n1</smiles><smiles>O=c1oc2ccccc2cc1-c1csc(N/N=C\c2cc(Br)ccc2O)n1</smiles> 


$\begin{array}{cccl} & & \\ & & \\ & & \\ \text { Compound } & (\text { Molecular formula) } & \text { Compound } & \\ 25 \mathrm{a} & \mathrm{C}_{14} \mathrm{H}_{13} \mathrm{ClN}_{2} \mathrm{O}_{2} \mathrm{~S} & 25 \mathrm{j} & \mathrm{C}_{11} \mathrm{H}_{8} \mathrm{ClFN}_{2} \mathrm{O}_{2} \mathrm{~S} \\ 25 \mathrm{~b} & \mathrm{C}_{13} \mathrm{H}_{11} \mathrm{~F}_{3} \mathrm{~N}_{2} \mathrm{O}_{2} \mathrm{~S} & 25 \mathrm{k} & \mathrm{C}_{11} \mathrm{H}_{7} \mathrm{~F}_{3} \mathrm{~N}_{2} \mathrm{O}_{2} \mathrm{~S} \\ 25 \mathrm{c} & \mathrm{C}_{13} \mathrm{H}_{11} \mathrm{~F}_{3} \mathrm{~N}_{2} \mathrm{O}_{3} \mathrm{~S} & 25 \mathrm{~N} & \mathrm{C}_{9} \mathrm{H}_{8} \mathrm{~N}_{2} \mathrm{O}_{3} \mathrm{~S} \\ 25 \mathrm{~d} & \mathrm{C}_{12} \mathrm{H}_{8} \mathrm{~F}_{4} \mathrm{~N}_{2} \mathrm{O}_{2} \mathrm{~S} & 25 \mathrm{~m} & \mathrm{C}_{15} \mathrm{H}_{12} \mathrm{~N}_{2} \mathrm{O}_{2} \mathrm{~S} \\ 25 \mathrm{e} & \mathrm{C}_{14} \mathrm{H}_{13} \mathrm{~N}_{3} \mathrm{O}_{2} \mathrm{~S} & 25 \mathrm{~N} & \mathrm{C}_{11} \mathrm{H}_{9} \mathrm{~N}_{2} \mathrm{O}_{2} \mathrm{~S} \\ 25 \mathrm{f} & \mathrm{C}_{12} \mathrm{H}_{9} \mathrm{~N}_{3} \mathrm{O}_{2} \mathrm{~S} & 25 \mathrm{~S} & \mathrm{C}_{11} \mathrm{H}_{7} \mathrm{Cl}_{3} \mathrm{~N}_{2} \mathrm{O}_{2} \mathrm{~S} \\ 25 \mathrm{~g} & \mathrm{C}_{9} \mathrm{H}_{8} \mathrm{~N}_{2} \mathrm{O}_{2} \mathrm{~S}_{2} & 25 \mathrm{p} & \mathrm{C}_{11} \mathrm{H}_{10} \mathrm{~N}_{2} \mathrm{O}_{2} \mathrm{~S} \\ 25 \mathrm{~h} & \mathrm{C}_{11} \mathrm{H}_{8} \mathrm{ClN}_{3} \mathrm{O}_{4} \mathrm{~S} & 25 \mathrm{~s} & \mathrm{C}_{11} \mathrm{H}_{9} \mathrm{BrN}_{2} \mathrm{O}_{2} \mathrm{~S} \\ 25 \mathrm{i} & \mathrm{C}_{11} \mathrm{H}_{8} \mathrm{~N}_{4} \mathrm{O}_{2} \mathrm{~S} & 25 \mathrm{t} & \mathrm{C}_{11} \mathrm{H}_{9} \mathrm{~N}_{3} \mathrm{O}_{4} \mathrm{~S}\end{array}$

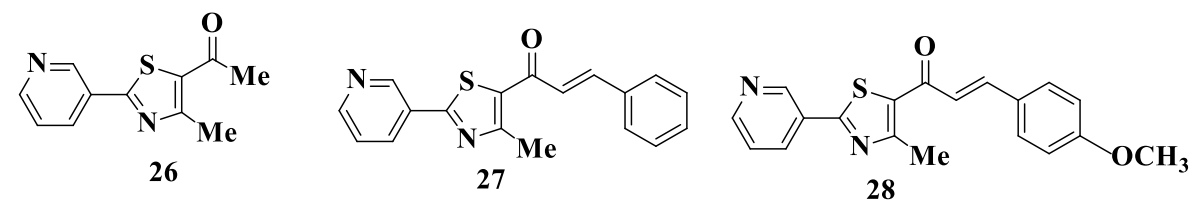<smiles>Cc1nc(-c2cccnc2)sc1C(=O)/C=C/c1ccccc1[N+](=O)[O-]</smiles>

29<smiles>COc1ccc(C2CN=C(c3sc(-c4cccnc4)nc3C)C2)cc1</smiles><smiles>Cc1nc(-c2cccnc2)sc1C1CC(c2ccc(F)cc2F)NN1</smiles>

32<smiles>[R][X]c1ccc(NCn2nc(-c3sc(NC(C)=O)nc3C)oc2=S)cc1</smiles>

33a-e

$\mathrm{R}=-33 \mathrm{a}-\mathrm{F}, \mathbf{- 3 3 b}-\mathrm{F},-33 \mathrm{c}-\mathrm{OCH}_{3},-33 \mathrm{~d}-\mathrm{NO}_{2},-33 \mathrm{e}-\mathrm{NO}_{2}$

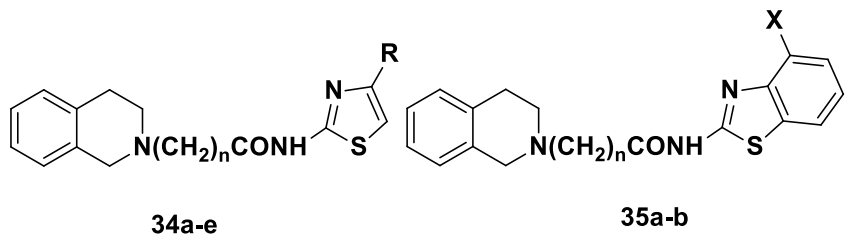

34a $\mathrm{R}=\mathrm{H} \mathrm{n}=1$ 34b R= $\mathrm{CH}_{3} \mathrm{n}=1$ 34c $\mathrm{R}=\mathrm{p}-\mathrm{CH}_{3} \mathrm{OC}_{6} \mathrm{H}_{4} \mathrm{n}=1$ 34d R=H n=2 34e R=p- $\mathrm{CH}_{3} \mathrm{OC}_{6} \mathrm{H}_{4} \mathrm{n}=2$ 35a $X=H \quad n=1$

$35 \mathrm{~b} X=\mathrm{Cl} n=1$ 
<smiles>CCOC(=O)c1sc(NC(=O)c2cc(OC)c(OC)c(OC)c2)nc1C</smiles>

36<smiles>CCOC(=O)c1sc(NC(=O)Nc2ccccc2)nc1C</smiles>

37<smiles>Cc1nc(NC(=O)Nc2ccccc2)sc1C(=O)NN</smiles>

38

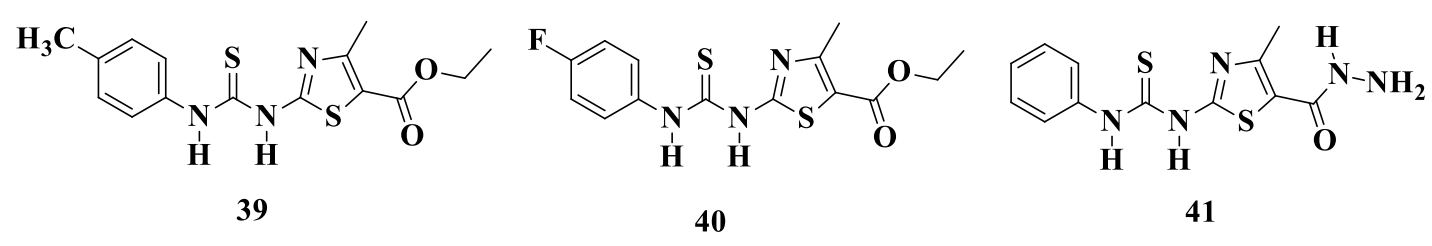

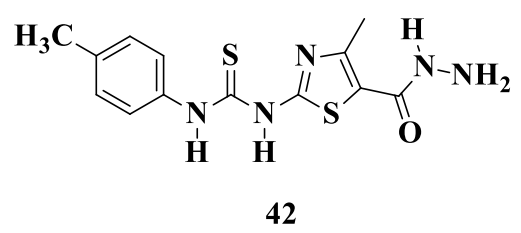<smiles>Cc1nc(NC(=S)Nc2ccc(F)cc2)sc1C(=O)NN</smiles>

43<smiles>COc1ccc(-c2ccc(-c3nc(C)sc3C)cc2)cc1</smiles>

44a

$\mathrm{O}_{2} \mathrm{~N}$<smiles>C=C(/C=C/c1cccc([N+](=O)[O-])c1)c1sc(NC)nc1C</smiles>

46<smiles>Cc1nc(-c2ccc(-c3ccc(F)c(C)c3)cc2)c(C)s1</smiles>

44b<smiles>Cc1ccc(-c2ccc(-c3nc(C)sc3C)cc2)cc1</smiles>

$44 c$<smiles>Nc1nc(-c2cc3c(ccc4ccccc43)oc2=O)cs1</smiles>

45<smiles>C=C(/C=C/c1ccccc1Cl)c1sc(NC)nc1C</smiles>

47<smiles>C=C(/C=C/c1ccc(OC)cc1)c1sc(NC)nc1C</smiles>

49<smiles>C=C(/C=C/c1ccccc1OC)c1sc(NC)nc1C</smiles>

50
48

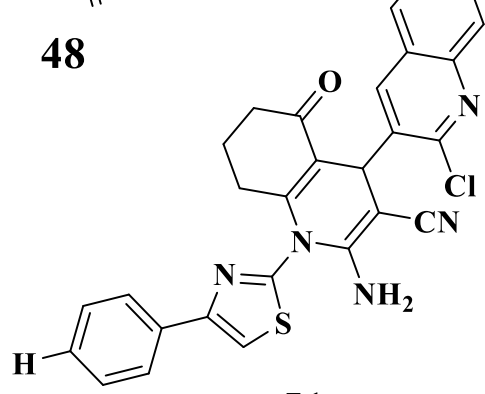

51 
<smiles>O=c1c2ccccc2nc(/C=C/c2ccccc2)n1-c1ncc(Br)s1</smiles>

52<smiles>O=c1c2ccccc2nc(/C=C/c2ccccc2[N+](=O)[O-])n1-c1ncc(Br)s1</smiles>

53<smiles>O=c1c2ccccc2nc(/C=C/c2ccc(Cl)cc2)n1-c1ncc(Br)s1</smiles>

54

Figure 3. Various thiazole derivatives used for antibacterial studies.

The derivative (23) was used to detect antibacterial activity against various bacteria. Amphotericin B and Fluconazole were used as standard drug molecules. From the antibacterial analysis data, it was found that 23 has excellent activity against various bacteria compared to the reference drug [42]. Arshad et al. reported a series of novel coumarin-based derivatives (24a-d) and examined the antibacterial activity against various bacteria using a broth dilution method. All the derivatives showed significant antibacterial activity against Staphylococcus aureus and Haemophilus influenza [43]. A series of new (2-aminothiazol-4-yl) methyl ester derivatives (25a-t) and demonstrated the antibacterial activity against various bacteria. All the synthesized derivatives showed prominent antibacterial activities as compared to the reference drug [44].

2-(3-pyridyl)-4,5-disubstituted thiazole derivatives (26-32) were used to study the antibacterial activity against various pathogens. All the derivatives showed prominent antibacterial activity as compared to the reference drug. It occurred due to the presence of both electron-withdrawing and donating groups [45]. A bunch of 1,3,4-oxadiazoles based thiazole derivatives (33a-e) was designed and ascribed the antibacterial activity by using the broth microdilution technique. All the derivatives showed superior activity as chloramphenicol, which acts as a reference drug molecule [46]. Jablotskaya et al. reported a series of compounds (34-35) and investigated the antibacterial activity against various bacteria using the agar-dish diffusion method. All the derivatives show excellent antibacterial activity compared to the reference drug molecules such as fluconazole and gentamicin [47]. Similarly, a series of thiazole derivatives (36-43) was reported by Rostom et al. and examined the antibacterial activity against various bacteria and pathogen through the agar diffusion method. Gentamicin and ampicillin trihydrate used as reference drug molecules. The authors found that all the derivatives show better antibacterial activity as compared to the reference drug molecule [48]. The antibacterial activities of a few novel thiazole derivatives (44a-c) were reported by Reddy et al. against various gram-positive and negative bacteria. It is observed that $44 \mathrm{c}$ has higher activity than 44a-b [49]. Coumarin-based thiazole derivative (45) was reported by El-Wahab et al. and investigated the biological activity against various bacteria using the paper disk diffusion technique. From the experimental data, it is observed that 45 shows significant antibacterial activity. The presence of coumarin moiety enhanced the antibacterial properties [50]. Based on the basic requirement of the effective antibacterial drug, Liaras et al. reported chalcone-based thiazole derivatives (46-50) and executed the biological activity using the microdilution method. It is observed that 46-50 showed potent activity against $S$. typhimurium, E.coli, M. flavus, and B. cereus [51]. Shah et al. designed and synthesized a novel thiazole derivative (51) and examined the antibacterial activity against various bacteria. The result revealed that 51 shows effective antibacterial activity against various bacteria [52]. Similarly, 
the novel thiazole derivatives (52-54) were used to detect the antibacterial activity against various pathogens using the cup-plate agar diffusion method. The experimental results found that all the derivatives showed potent activity against $P$. aeruginosa, B. subtilis bacteria [53].<smiles>O=C(NNc1nc(Nc2nccs2)nc(Nc2ccccc2[N+](=O)[O-])n1)c1ccncc1</smiles>

55<smiles>Cc1nc(NNC(=O)c2ccncc2)nc(Nc2nccs2)n1</smiles><smiles>Cc1ccccc1N</smiles>

56<smiles>O=C(NNc1nc(Nc2ccc(F)cc2)nc(Nc2nccs2)n1)c1ccncc1</smiles>

57<smiles></smiles><smiles>CCN(CC)Cc1cc(NNc2nc(-c3ccccc3)cs2)ccc1O</smiles>

60<smiles></smiles><smiles>Nc1nc(NNc2ccc(O)c(CCN3CCCCC3)c2)c(-c2ccccc2)s1</smiles><smiles>Cc1ccc(-c2nc(N)sc2NNc2ccc(O)c(CN(C)C)c2)cc1</smiles> 


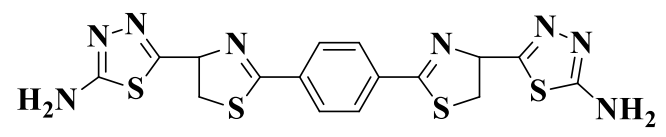

64

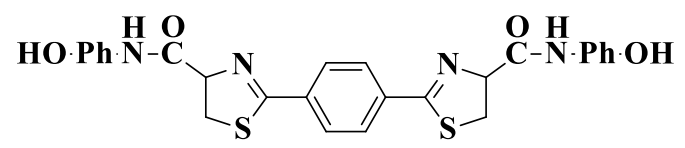

65<smiles>O=C(Nc1nc2ccc(O)cc2s1)C1CSC(c2ccc(C3=NC(C(=O)Nc4nc5ccc(O)cc5s4)CS3)cc2)=N1</smiles>

66<smiles>Oc1ccc(N=NC2=NC(c3nnc(N=Nc4ccc(O)cc4O)s3)CS2)c(O)c1</smiles>

67

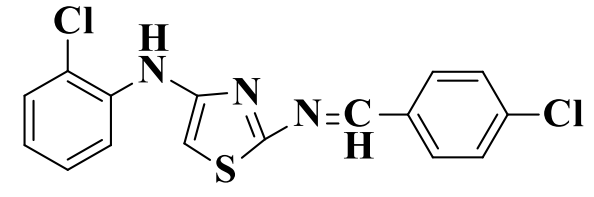

$68 \mathbf{a}$<smiles></smiles>

$68 b$<smiles>O=C(Nc1nc(-c2ccccc2)cs1)c1ccc([N+](=O)[O-])cc1</smiles>

69<smiles>O=C(Nc1nc(-c2ccc([N+](=O)[O-])cc2)cs1)c1ccccc1</smiles><smiles>O=[N+]([O-])c1ccc(C=Nc2nc(-c3ccccc3)cs2)cc1</smiles><smiles>COc1ccc(C(=O)Nc2nc(-c3ccccc3)cs2)cc1</smiles>

70<smiles>COc1ccc(/C=N/c2nc(-c3ccccc3)cs2)cc1OC</smiles><smiles>COc1ccc(C(=O)Nc2nc(-c3ccc([N+](=O)[O-])cc3)cs2)cc1</smiles><smiles>[R][X]1cccc(/C=N/n2cnnc2CSc2nc3ccccc3s2)c1</smiles>

(75a-d)

$75 \mathrm{a}=-\mathrm{H}, \mathrm{b}=-4 \mathrm{NO}_{2}, \mathrm{c}=-2 \mathrm{Cl}, \mathrm{d}=-2 \mathrm{OH}$ 


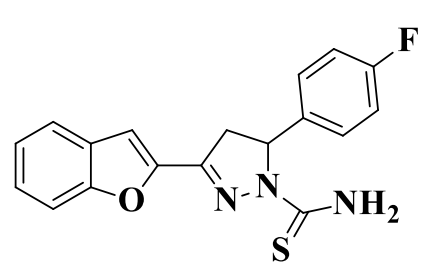

76<smiles>Cc1nc(N2N=C(c3cc4ccccc4o3)CC2c2ccc(F)cc2)sc1N=N</smiles>

77<smiles>Fc1ccc(C2CC(c3cc4ccccc4o3)=NN2c2nc(-c3ccc(Cl)cc3)cs2)cc1</smiles>

78<smiles>Clc1ccc(I)cc1</smiles><smiles>Cc1ccc(-c2nc(C=NNC(N)=S)cs2)cc1</smiles>

79a<smiles>Cc1ccc(-c2nc(C)c(C=NNC(N)=S)s2)cc1</smiles><smiles>CC(=NNC(N)=S)c1sc(-c2ccccc2)nc1C</smiles>

79c<smiles>N#CC(C#N)=C1NC(c2ccccc2)=CS1</smiles><smiles>Nc1n[nH]c(N)c1-c1nc(-c2ccccc2)cs1</smiles>

80b<smiles>CC(=NNC(N)=S)c1sc(-c2ccc(F)cc2)nc1C</smiles><smiles>N#CC(C#N)=c1nc(-c2ccccc2)/c(=C\c2ccccc2)s1</smiles>

80c<smiles>[R]c1ccc2oc(=O)c(-c3csc(N4N=C(c5ccccc5)CC4c4cc5ccccc5nc4Cl)n3)cc2c1</smiles>

81a) $R=F, R 1=2-F$; b) $R=F, R 1=3-F$; c) $R=F, R 1=4-F$<smiles>[R]c1csc(NNC(=O)Cn2c(C)nc(N=Nc3ccccc3)c2[N+](=O)[O-])n1</smiles> 


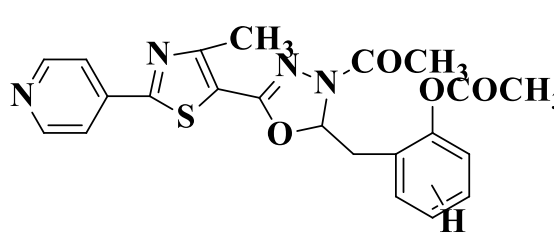

83

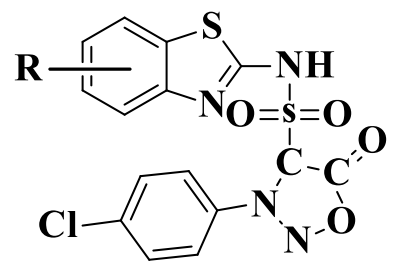

86a-b

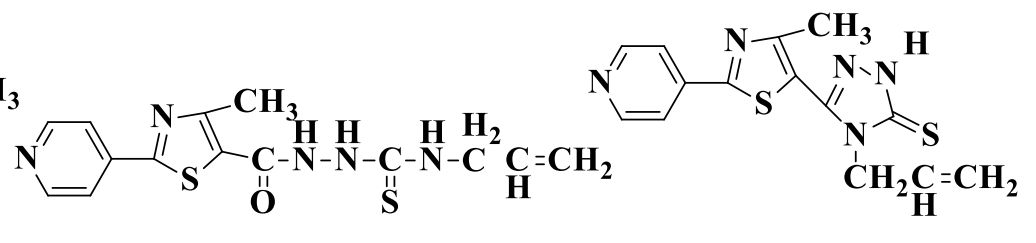

84

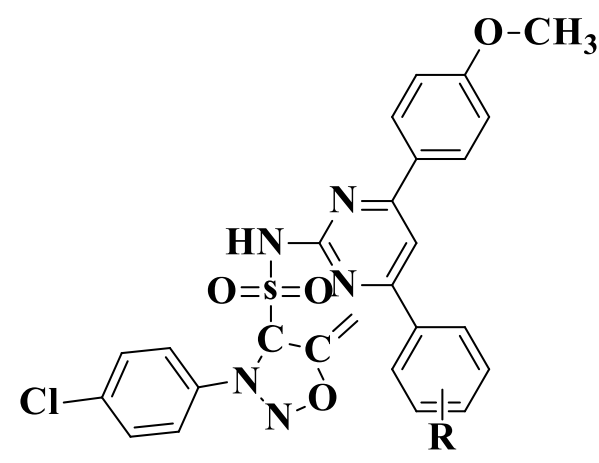

87a-e

(86a) $\mathrm{R}=6-\mathrm{OCH}_{3} ;(86 \mathrm{~b}) \mathrm{R}=5-\mathrm{CH}_{3} ;(87 \mathrm{a}) \mathrm{R}=3-\mathrm{NO}_{2} ;(87 \mathrm{~b}) \mathrm{R}=4-\mathrm{NO}_{2} ;(87 \mathrm{c}) \mathrm{R}=4-\mathrm{Cl}$; (87d) $\mathrm{R}=4-\mathrm{OCH}_{3} ;(87 \mathrm{e}) \mathrm{R}=3-\mathrm{OCH}_{3}$

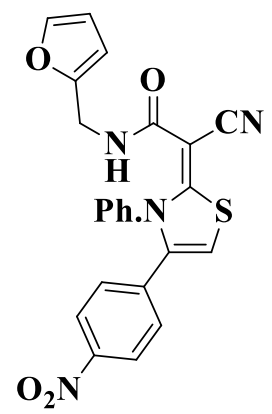

88

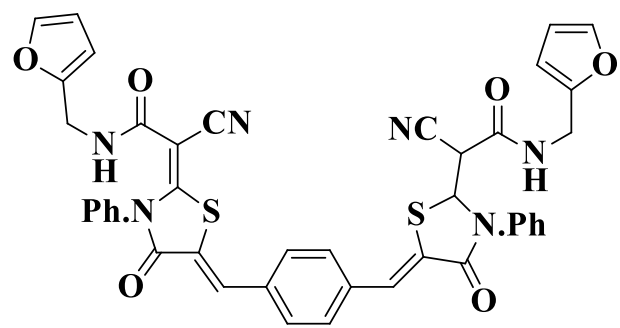

91

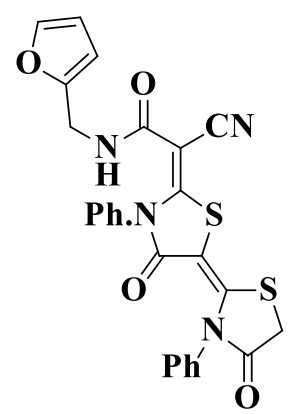

89

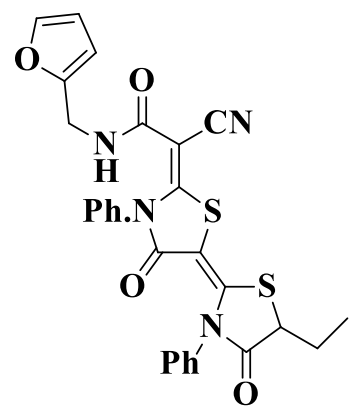

90<smiles>N#C/C(C(=O)NCc1ccco1)=c1\s/c(=C\[Al])c(=O)n1-c1ccccc1</smiles>

(92a, 93a)

92a: $\mathrm{Ar}=\mathrm{C6H} 4 \mathrm{Cl}-\mathrm{o}$

93b: $A r=C 6 H 4 B r-0$ 

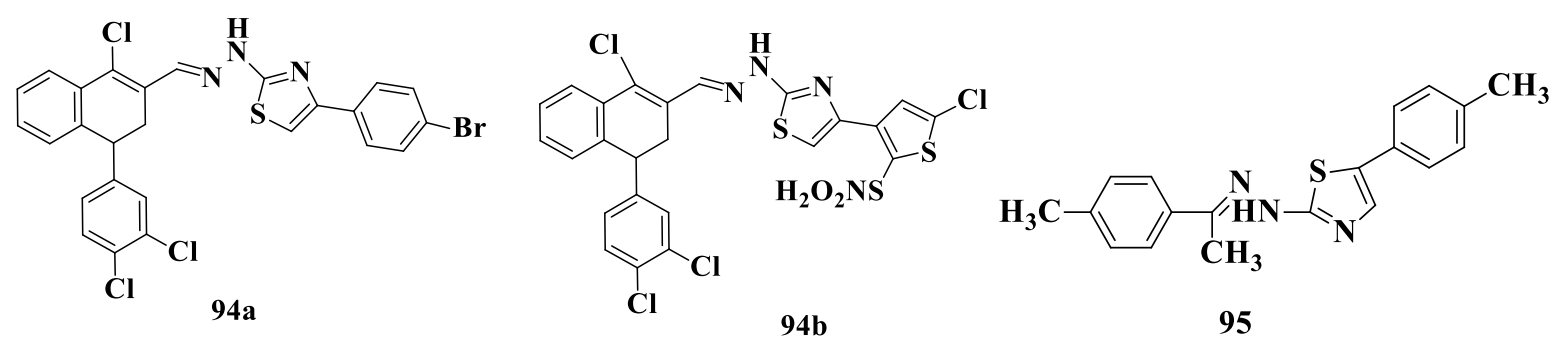<smiles>[R]c1ccc(NCn2nc(-c3sc(NC(=O)c4ccc(C)cc4)nc3C)oc2=O)cc1</smiles>

96a-f

\section{a; -2-F, b; -3-F, c;-4-F, d;-2-NO,$~ e ;-3-\mathrm{NO}_{2}$ f;-4-NO}

Figure 4. Various thiazole derivatives used for antibacterial studies.

Desai et al. reported a bunch of 1,3,5-triazine based triazole derivatives (55-57) and envisaged the biological activity against various pathogens by using the Mueller Minton broth dilution method. All the derivatives showed potent activity against E. coli, S. aureus, P. aeruginosa, and $S$. pyogenes [54]. The biological activities of 2-phenylamino-thiazole derivative (58) displayed by using the Mueller Hinton broth dilution method against various pathogens. It revealed that 58 has excellent biological activity against $C$. albicans and C. krusei like bacteria [55]. It is well known that Schiff bases have numerous biological activities such as antibacterial, antifungal and antitumor, and so on. In this regard, Etaiw et al. reported 2aminobenzothiazole derivative (59) and 59-M complexes ( $\mathrm{M}=\mathrm{Ni}(\mathrm{II}), \mathrm{Cu}(\mathrm{II})$, and $\mathrm{Zn}(\mathrm{II})$ ). The experimental results show that the complexes (59-M) show better antibacterial activity than 59 by using the agar diffusion technique [56]. A series of thiazole derivatives (60-63) were used for biological activity using the agar dilution method against various bacteria. All the derivatives showed excellent antibacterial activity against gram-positive and negative bacteria. The authors reported that all the derivatives showed potent activity compared to the reference drug molecule [57]. The novel thiazole derivatives (64-67) showed prominent antibacterial activity against various bacteria and pathogens using the agar diffusion method [58]. Schiff base derivatives (68a-b) exhibited potent antibacterial activity against $B$. subtilis, S. aureus, $K$. pneumonia, and E. coli by using the paper disc technique [59]. The novel thiazole derivatives (69-73) were employed for antibacterial activity against various pathogens using the tube dilution technique. The authors reported that 69, 72, and 73 exhibited potent antibacterial activity than 70 and 71 . It is due to the presence of electrons withdrawing $\left(-\mathrm{NO}_{2}\right)$ groups [60]. The derivative (74) showed antibacterial activity against B. cereus bacteria by using the agar process. The antibacterial property of 94 is better than the reference drug ampicillin [61]. The derivatives (75a-d) envisaged prominent activity against $B$. subtilis, E. coli, K. pneumonia, and $P$. aeuroginosa bacteria by using nutrient agar medium [62]. To make more targeted antibacterial drug agent, the antibacterial activities of a few fluorinated-2(3-(benzofuran-2yl)pyrazol-1-yl)thiazole derivatives (76-78) were evaluated against B. subtilis and $S$. aureus. 
Ciprofloxacin is used as a reference drug molecule. The result showed that 76-78 have energetic antibacterial activity against various bacteria compared to reference drugs. [63]. similarly, the derivatives (79a-d) exhibited potent antibacterial activity against $E$. coli and $B$. subtilis using the well-plate technique [64]. The thiazole derivatives (80a-c) showed better antbacterial activity than the references drug cefuroxime and nitrofurantoin [65]. A series of novel 3-(2-(5-(2-chloroquinoline-3-yl)-3-substituted phenyl-4,5-dihydro-1H-pyrazol-1-yl)thiazol-4yl)-6-H/halo-2H-chromen-2-ones derivatives (81a-c) was reported by Ansari et al. The antibacterial activity was examined by using serial plate dilution technique. All the derivatives exhibited powerful antimicrobial activity against E.coli and S.aureus [66]. The derivatives (82a-b) envisaged better antibacterial activity against various pathogens by using the cup-plate method [67]. The derivatives (83-85) exhibited potent antibacterial activity against $C$. albicans, B. cereus, and L. monocytogenes bacteria by using the cup-plate agar diffusion method [68]. Asundaria et al. reported a series of novel thiazole derivatives (86-87). The derivatives showed prominent activities against various pathogens [69]. The derivatives (88-93) ascribed potent antibacterial activity against various pathogens by using the agar diffusion method [70]. Chidananda et al. reported a novel thiazole derivative (94a-b) and examined their biological activity against various bacteria by using the disc diffusion technique. The authors confirmed that 94a-b have effective biological activity against $P$. aeruginosa and $E$. coli like bacteria [71]. The derivative (95) displayed moderate antibacterial activity against various pathogens using the agar plate technique [72]. Many novel 1,3,4-oxadiazoles based thiazole derivatives (96a-f) were designed and envisaged antibacterial properties by using the broth dilution method. The derivatives ascribed potent activities against $S$. pyogenes and $P$. aeruginosa like bacteria [73].<smiles>[R]=Cc1ccccc1/C=N/c1c(C(=O)N/N=C/c2cc3ccccc3nc2Cl)sc(=S)n1-c1ccccc1</smiles>

97a-b

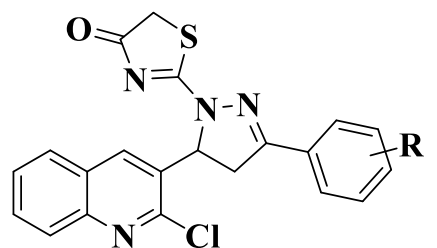

(98a-e)

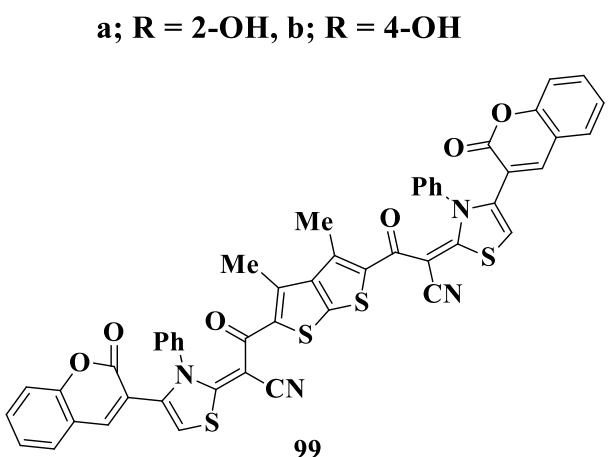

$\mathrm{R} ; \mathrm{a} ;=2-\mathrm{Cl}, \mathrm{b} ;=2-\mathrm{F}, \mathrm{c} ;=3-\mathrm{F}, \mathrm{d} ;=4-\mathrm{F}, \mathrm{e} ;=4-\mathrm{NO}_{2}$

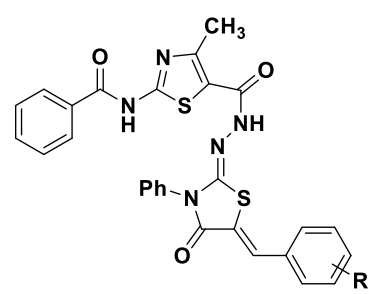

(100a-f)

$\mathrm{R} ; \mathrm{a} ;=-2-\mathrm{OH}, \mathrm{b} ;=-4-\mathrm{OH}, \mathrm{c} ;=-2-\mathrm{CH}_{3}, \mathrm{~d} ;=-4-\mathrm{CH}_{3}, \mathrm{e} ;=-2-\mathrm{OCH}_{3}, \mathrm{f} ;=-4-\mathrm{OCH}_{3}$ 


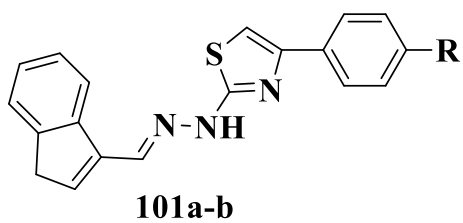

R; 101a;-H, b;-OCH3

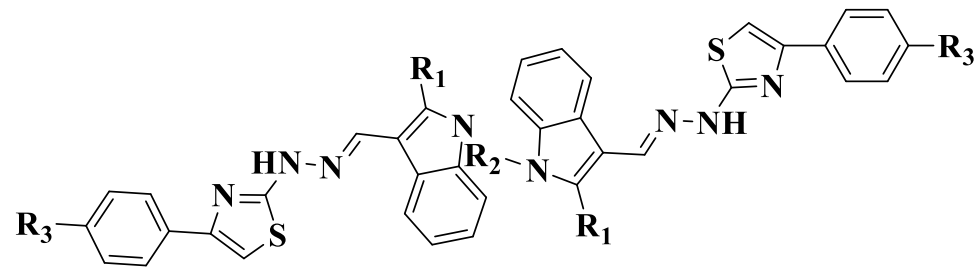

102a-d

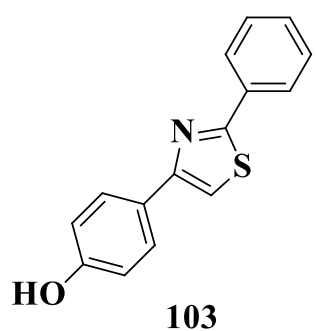

103
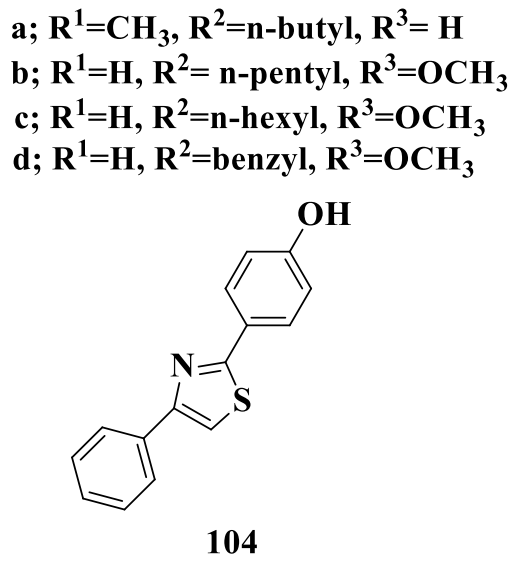

Figure 5. Various thiazole derivatives used for antibacterial studies.

Due to the enhancement of the mortality rate, it is required to discover new antibacterial drugs with a novel mode of action towards bacteria pathogen without any side effect. In this regard, Desai et al. designed some novel quinolone-thiazole derivatives (97a-b) and performed their antibacterial screening by using a broth dilution technique. The antimicrobial screening data showed that 97a-b have potent biological significance towards S.aureus, E.coli, S.pyogenes, and P.aeruginosa [74]. Desai et al. reported a bunch of active thiazole derivatives (98a-d) having a quinolone-pyrazoline backbone and examined their biological activity against various bacteria pathogens. It has been found from the antimicrobial screening data that all the derivatives have considerable antibacterial activity against various gram bacteria. Ampicillin and griseofulvin were used as reference molecules [75]. The thiophene-based thiazole derivative (99) shows moderate antibacterial activity against various pathogens. Streptomycin and Penicillin were used as reference molecules [76]. To effectively treat bacterial disease caused by infectious bacteria, it is very important to develop an effective antibacterial drug with great accuracy. On that aspect of research, Desai et al. synthesized some novel thiazole and thiazolidine derivatives (100a-f) and analyzed their biological characteristic by using broth dilution techniques against infectious bacteria. The result was that 100a-f has strong antibacterial activity due to electron-donating groups [77]. Indole and its derivative have significant biological activities like antibacterial, antifungal, anticancer, etc. So, the addition of indole moieties with biologically active heterocyclic thiazole derivative creates hope of producing a potent antibacterial drug to reduce the bacterial mortality rate. Mahmoodi et al. synthesized a series of derivatives (101-102) and examined their antibacterial activity against P.aeruginosa and B.subtilis. The authors reported that all the derivatives showed prominent biological activity against the various bacteria [78]. The compounds (103-104) have powerful biological activity against various gram bacteria by using the agar diffusion technique [79]. 

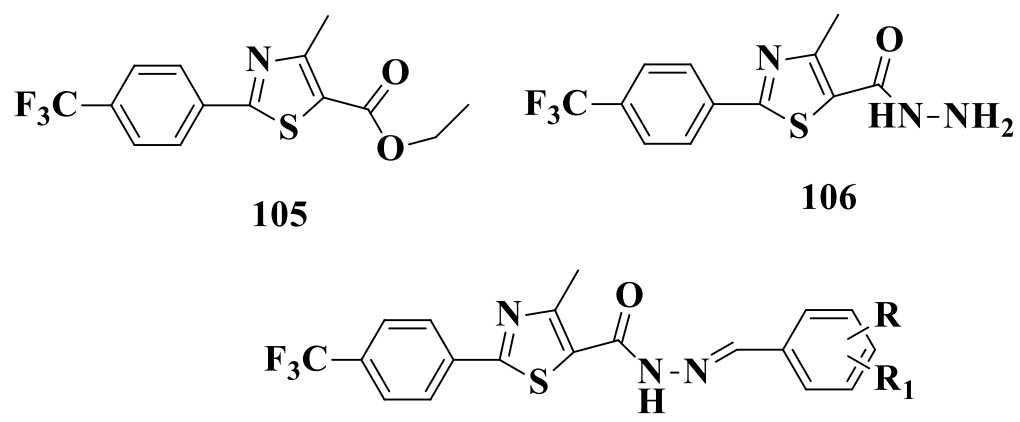

(107-111)

$\left.\left.\left.\left.\left.\mathrm{R} / \mathrm{R}_{1} ; 107\right)=\mathrm{H} / 4-\mathrm{Br}, 108\right)=\mathrm{H} / 4-\mathrm{F}, 109\right)=\mathrm{H} / 4-\mathrm{OH}, 110\right)=2-\mathrm{Cl} / 4-\mathrm{Cl}, 111\right)=2-\mathrm{Cl} / 6-\mathrm{Cl}$.

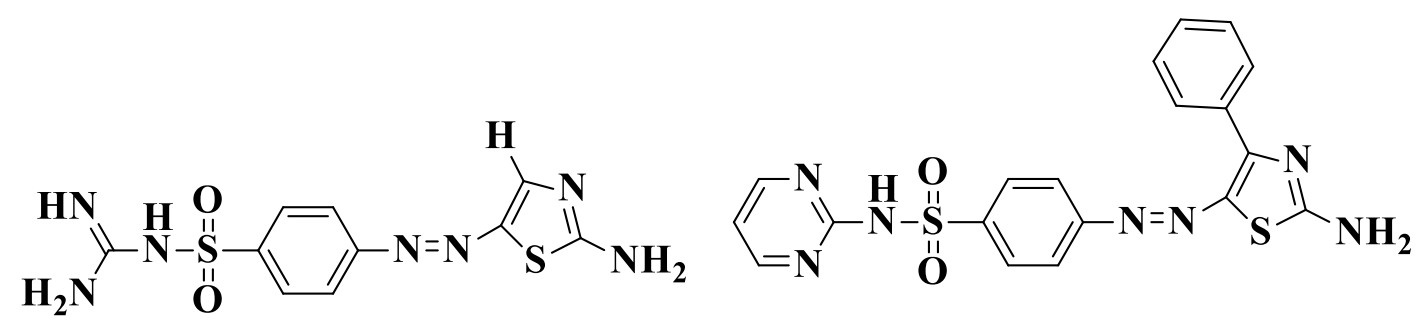

$112 \mathrm{a}$

$112 b$

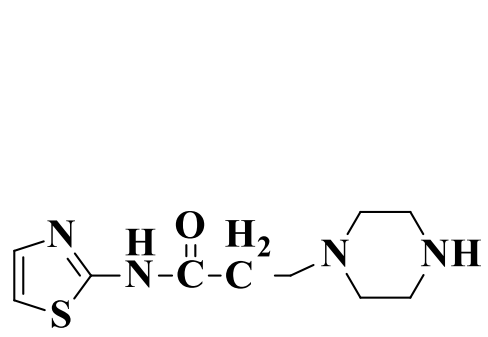

113

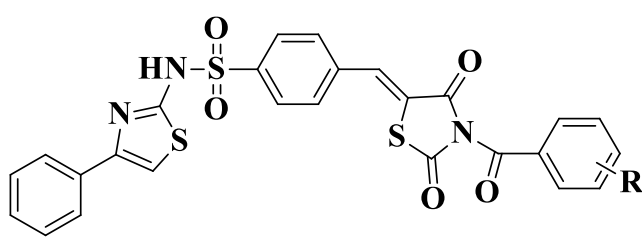

114a-d

$\left.\left.\mathrm{R} ; \mathrm{a})=4-\mathrm{CH}_{3}, \mathrm{~b}\right)=2-\mathrm{Cl}, \mathrm{c}\right)=4-\mathrm{Cl}$. d) $=2,4-\mathrm{NO}_{2}$

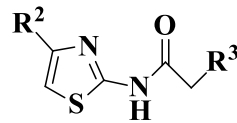

115a-g
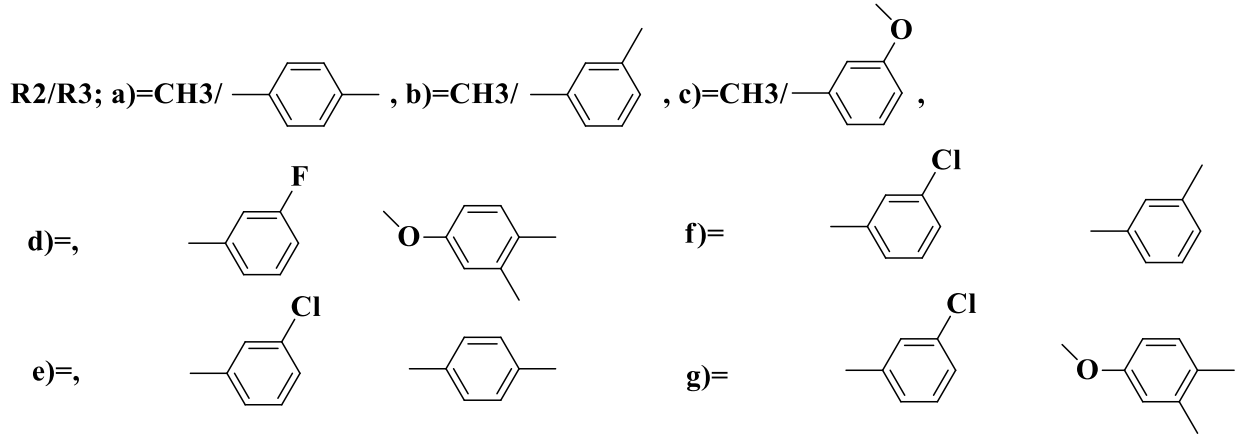


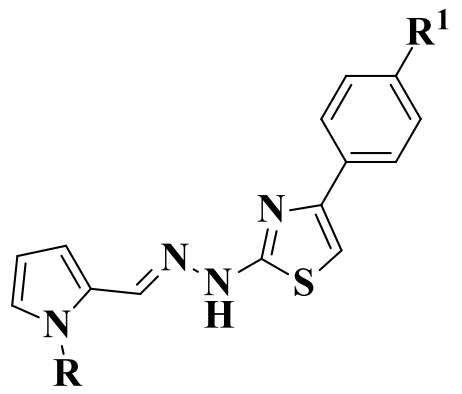

$\begin{array}{lll}\text { a } & \mathrm{H} & \mathrm{H} \\ \text { b } & \mathrm{H} & \mathrm{Br} \\ \text { c } & \mathrm{H} & \mathrm{Cl} \\ \text { d } & \mathrm{CH}_{3} & \mathrm{CH}_{3} \\ \mathrm{e} & \mathrm{CH}_{3} & \mathrm{Br} \\ \mathrm{f} & \mathrm{CH}_{3} & \mathrm{~F}\end{array}$

\section{6a-f}<smiles>[R5]c1ccc(-c2nn(-c3ccccc3)cc2C2CC(c3cc([R4])c([R4])c([R4])c3[R1])=NN2c2nc(-c3cc(Cl)ccc3O)cs2)cc1</smiles>

\begin{tabular}{|c|c|c|c|c|c|}
\hline Product & $\mathbf{R}_{1}$ & $\mathbf{R}_{2}$ & $\mathbf{R}_{\mathbf{3}}$ & $\mathbf{R}_{4}$ & $\mathbf{R}_{5}$ \\
\hline $\mathbf{a}$ & OH & H & H & Cl & $\mathbf{O H}$ \\
\hline b & OH & H & OH & $\mathbf{H}$ & $\mathbf{O H}$ \\
\hline c & OH & Cl & OH & $\mathrm{Cl}$ & $\mathrm{OH}$ \\
\hline d & $\mathbf{O H}$ & $\mathbf{H}$ & $\mathbf{O H}$ & $\mathbf{H}$ & $\mathrm{Cl}$ \\
\hline $\mathbf{e}$ & OH & Cl & OH & Cl & Cl \\
\hline
\end{tabular}

117a-e

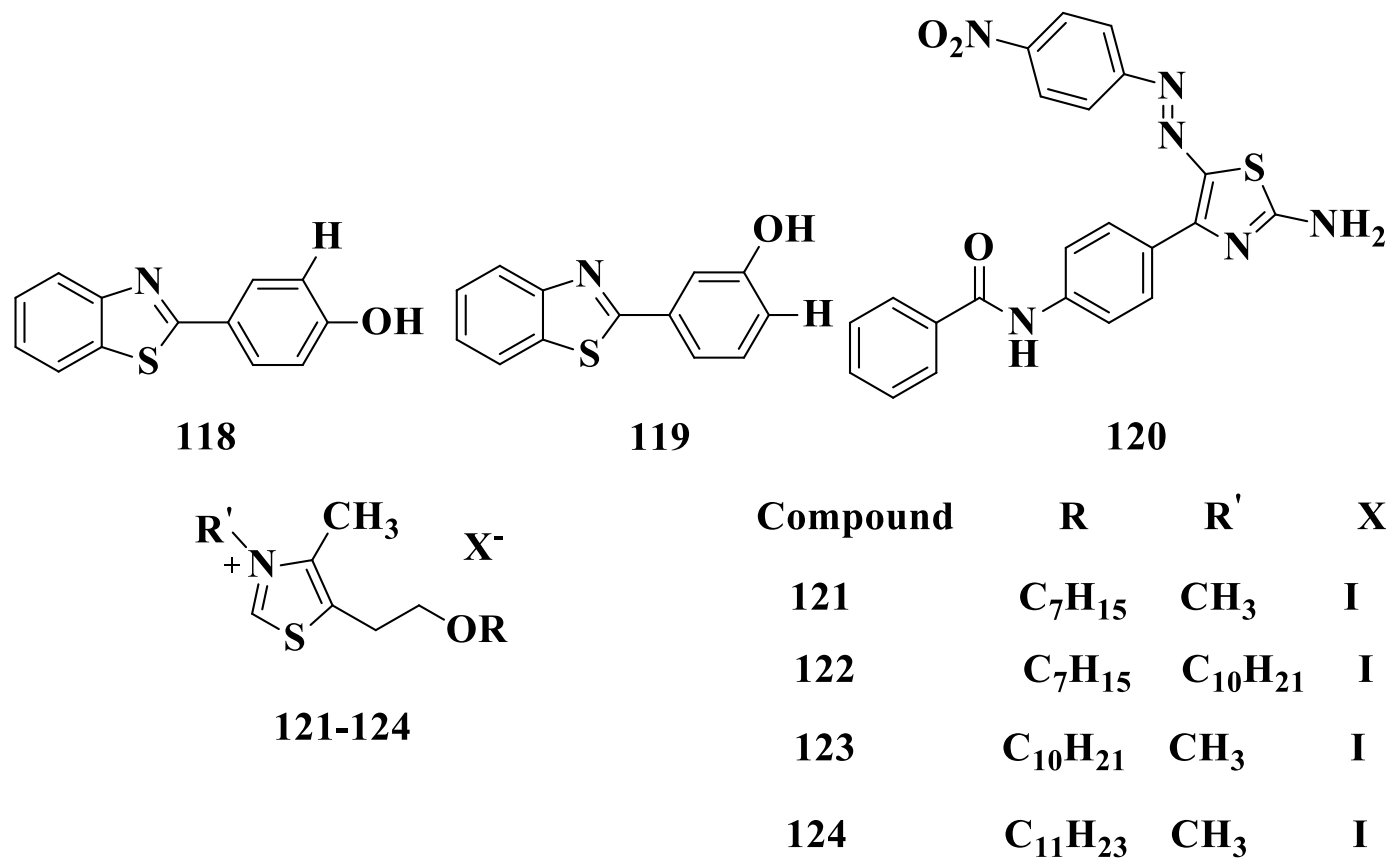

Figure 6. Various thiazole derivatives used for antibacterial studies.

Nastasa et al. depicted the synthesis of new hydrazone bearing thiazole derivatives (105-111) and performed their antibacterial properties using the agar diffusion technique. The result showed that the compounds 105-111 have potent biological activity against S.aureus and E.coli like bacteria [80]. From the literature, it is well documented that azo dyes have active biological activities like antibacterial, antifungal, etc. Gaffer et al. reported a series of aryl azothiazole derivatives (112a-b) and examined their biological activity by using the agar diffusion method. The antimicrobial analysis data confirmed that the derivatives $112 \mathrm{a}-\mathrm{b}$ have 
a formidable antibacterial response towards various gram-positive bacteria [81]. By using the cup-plate agar diffusion method, the authors found that 113 has considerable antibacterial activity against various gram-positive bacteria [82]. Thiazole and thiazolidinone derivatives of thiazolidine have a strong antimicrobial impact. Parekh et al. reported a few derivatives (114ad) and examined their antimicrobial screening properties by using the microdilution method. From the experimental data, it is observed that $114 \mathrm{a}-\mathrm{d}$ have incredible antibacterial activity towards B.subtilis and S.aureus like bacteria [83]. By using the disc diffusion technique, it is observed that 115a-g have profound biological activity against K.pneumonia, E.coli, S.aureus, and P.aeruginosa like bacteria [84]. Yurttas et al. discovered a series of new hydrazone bridged thiazole-pyrrole derivatives (116a-f) and examined their antimicrobial activity using the broth dilution method. The biological analysis data found that nearly all the compounds show potent antimicrobial activity towards various bacteria [85]. By using the nutrient agar plate seeded technique, it is found that $117 \mathrm{a}$-e has potent antibacterial activity against E.coli and P.vulgaries like bacteria due to electron-rich nitrogen heterocycles [86]. The authors found that 1,3-thiazole derivatives (118-119) have potent biological activity against various gram-positive and negative bacteria using the clay-pot process [87]. The derivative (120) displayed potent antibacterial activity towards Bacillus licheniformis, Enterobacter cloacae, and E.coli-like bacteria due to incorporating the 4- $\mathrm{NO}_{2}$ group [88]. By using the agar-dish diffusion method, it is found that 121-124 have strong inhabitation against gram-positive bacteria [89].

\section{Conclusions and Future Prospects}

The development of efficient and targeted drugs is a demandable interest for medicinal chemists. Thiazole derivative drugs have achieved a triumphant place in the pharmacological research field because of their utilization as therapeutic agents to control various bacterial disorders. A number of thiazole derivatives are in clinical trials and may be used as an active antibacterial agent in the future. This review provides a magnificent understanding of thiazole derivatives in the field of bacterial therapy against different bacteria. Data collected from the numerous reported articles conclude that those thiazole derivatives have excellent heterocyclic scaffolds with enormous antibacterial activity. This review is also signifying that the potential of the thiazole nucleus for the improvement of new drug therapy of bacterial diseases and disorder become increasing day to day as various patent has been filed based on thiazole derivative. This review will provide a suitable path for the scheming of thiazole-based antibacterial active agents. Hence, this review will contribute insight into the design and development of novel and selective thiazole derivatives based on their recent trends in bacterial diseases.

\section{Funding}

Dr. Jali acknowledges a fund from DST, India, by EMEQ project (No.-EEQ/2019/000091). The authors also thank the Department of Chemistry, VSSUT, Burla, for providing a research facility.

\section{Acknowledgments}

Dr. Jali thank the Department of Chemistry, VSSUT, Burla, for providing a research facility. 


\section{Conflicts of Interest}

The authors have declared that no competing interests exist.

\section{References:}

1. Mishra, I.; Mishra, R.; Mujwar, S.; Chandra, P. A retrospect on antimicrobial potential of thiazole scaffold. J. Heterocycl. Chem 2020, 57, 2304-2329, https://doi.org/10.1002/jhet.3970.

2. Jali, B. R.; Behura, R.; Barik, S. R.; Parveen, S.; Mohanty, S. P.; Das, R. A Brief Review: Biological Implications of Naphthoquinone Derivatives. Res $J$ Pharm Techno 2018, 11, 3698-3702, https://doi.org/10.5958/0974-360X.2018.00679.0.

3. Leoni, A.; Locatelli, A.; Morigi, R.; Rambaldi, M. Novel thiazole derivatives: a patent review (2008-2012; Part 1). Expert Opinion on Therapeutic Patents 2013, 24, 201-216, https://doi.org/10.1517/13543776.2014.858121.

4. Leoni, A.; Locatelli, A.; Morigi, R.; Rambaldi, M. Novel thiazole derivatives: a patent review (2008-2012. Part 2).Expert Opinion on Therapeutic Patents 2014, 24, 759-777, https://doi.org/10.1517/13543776.2014.910196.

5. Mishra, C. B.; Kumari, S.; Tiwari, M. Thiazole A promising heterocycle for the development of potent CNS active agents. Eur J Med Chem. 2015, 92, 1-34, https://doi.org/10.1016/j.ejmech.2014.12.031.

6. Jali, B. R.; Kuang, Y.; Neamati, N.; Baruah, J. B. Selective binding of naphthoquinone derivatives to serum albumin proteins and their effects on cytotoxicity. Chem.-Biol. Interact. 2014, 214, 10-17, https://doi.org/10.1016/j.cbi.2014.01.014.

7. Behera, S.; Behura, R.; Mohanty, M.; Dinda, R.; Mohanty, P.; Verma, A. K.; Sahoo, S. K.; Jali, B. R. Spectroscopic, cytotoxicity and molecular docking studies on the interaction between 2,4dinitrophenylhydrazine derived Schiff bases with bovine serum albumin. Sensors International 2020, 1, 100048, https://doi.org/10.1016/j.sintl.2020.100048.

8. Pathak, N.; Rathi, E.; Kumar, N.; Kini, S. G.; Rao, C. M. A Review on Anticancer Potentials of Benzothiazole Derivatives. Mini-Rev. Med. Chem 2020, 20, 12-23, https://doi.org/10.2174/1389557519666190617153213.

9. Siddiqui, N.; Arshad, M. F.; Ahsan, W.; Alam, M. S. Thiazoles: a valuable insight into the recent advances and biological activities. Int. J. Pharm Sci. Drug Res 2009, 1, 136-143, https://ijpsdr.com/index.php/ijpsdr/article/view/46.

10. Kamal, A.; Syed, M. A. H.; Mohammed, S. M. Therapeutic potential of benzothiazoles: a patent review (2010-2014). Expert opinion on therapeutic patents 2015, 25, 335-349, https://doi.org/10.1517/13543776.2014.999764.

11. Kashyap, S. J.; Garg, V. K.; Sharma, P. K.; Kumar, N.; Dudhe, R.; Gupta, J. K. Thiazoles: having diverse biological activities. Med Chem Res 2012, 21, 2123-2132, https://doi.org/10.1007/s00044-011-9685-2.

12. Shi, Y.; Zhou, C. H. Synthesis and evaluation of a class of new coumarin triazole derivatives as potential antimicrobial agents. Bioorganic Med Chem Lett 2011, 21, 956-960, https://doi.org/10.1016/j.bmcl.2010.12.059.

13. Behera, S.; Behura, R.; Mohanty, M.; Sahoo, M.; Ramakrishna, D. S.; Jali, B. R. Study of Interaction Between Bovine Serum Albumin and Dolutegravir Intermediate: Fluorescence and Molecular Docking Analysis. Biointerface Res. Appl. Chem. 2021, 11, 13102-13110, https://doi.org/10.33263/BRIAC115.1310213110.

14. Singh, I. P.; Gupta, S.; Kumar, S. Thiazole Compounds as Antiviral Agents: An Update. Med Chem 2020, 16, 4-23, https://doi.org/10.2174/1573406415666190614101253.

15. Zhang, L.; Liu, X.; Lu, S.; Liu, J.; Zhong, S.; Wei, Y.; Bing, T.; Zhang, N.; Shangguan, D. Thiazole Orange Styryl Derivatives as Fluorescent Probes for G-Quadruplex DNA. ACS Appl. Bio Mater. 2020, 3, 2643-2650, https://doi.org/10.1021/acsabm.9b01243.

16. Soliman, N. N.; Salam, M. A. EI.; Fadda, A. A.; Motaal, M. A. Synthesis, Characterization, and Biochemical Impacts of Some New Bioactive Sulfonamide Thiazole Derivatives as Potential Insecticidal Agents against the Cotton Leafworm, Spodoptera littoralis. J. Agric. Food Chem. 2020, 68, 5790-5805, https://doi.org/10.1021/acs.jafc.9b06394.

17. Li, Y.; Sun, N.; Ser, H.-L.; Long, W.; Li, Y.; Chen, C.; Zheng, B.; Huang, X.; Liu, Z.; Lu, Y.-J. Antibacterial activity evaluation and mode of action study of novel thiazole-quinolinium derivatives. RSC Adv. 2020, 10 , 15000-15014, https://doi.org/10.1039/D0RA00691B. 
18. Sharma, P. C.; Bansal, K. K.; Sharma, A.; Sharma, D.; D, Aakash. Thiazole-containing compounds as therapeutic targets for cancer therapy. Eur. J. Med. Chem 2020, 188, 112016, https://doi.org/10.1016/j.ejmech.2019.112016.

19. Sayed, A. R.; Gomha, S. M.; Taher, E. A.; Muhammad, Z. A.; El-Seedi, H. R.; Gaber, H. M.; Ahmed, M. M. One-Pot Synthesis of Novel Thiazoles as Potential Anticancer Agents. Drug Des Devel Ther. 2020, 14, 13631375, https://doi.org/10.2147/DDDT.S221263.

20. Yu, B.; Zhou, S.; Cao, L.; Hao, Z.; Yang, D.; Guo, X.; Zhang, N.; Bakulev, V. A.; Fan, Z. Design, Synthesis, and Evaluation of the Antifungal Activity of Novel Pyrazole-Thiazole Carboxamides as Succinate Dehydrogenase Inhibitors. J. Agric. Food Chem. 2020, 68, 27, 7093-7102, https://doi.org/10.1021/acs.jafc.0c00062.

21. Mohammad, H.; Eldesouky, H. E.; Hazbun, T.; Mayhoub, A. S.; Sellemm, M. N. Identification of a Phenylthiazole Small Molecule with Dual Antifungal and Antibiofilm Activity Against Candida albicans and Candida auris. Sci Rep 2019, 9, 18941, https://doi.org/10.1038/s41598-019-55379-1.

22. Biernasiuk, A.; Kawczyńska, M.; Berecka-Rycerz, A.; Rosada, B.; Gumieniczek, A.; Malm, A.; Dzitko, K.; Laczkowski, K. Z. Synthesis, antimicrobial activity, and determination of the lipophilicity of ((cyclohex-3enylmethylene)hydrazinyl)thiazole derivatives. Med Chem Res 2019, 28, 2023-2036, https://doi.org/10.1007/s00044-019-02433-2.

23. Adole, V. A.; More, R. A.; Jagdale, B. S.; Pawar, T. B.; Chobe, S. S. Efficient Synthesis, Antibacterial, Antifungal, Antioxidant and Cytotoxicity Study of 2-(2-Hydrazineyl)thiazole Derivatives. Chemistry Select 2020, 5, 2778-2786, https://doi.org/10.1002/slct.201904609.

24. Pricopie, A.-I.; Focsan, M.; Ionut, I.; Marc, G.; Vlase, L.; Gaina, L.-I.; Vodnar, D. C.; Simon, E.; Barta, G.; Pirnau, A.; Oniga, O. Novel 2,4-Disubstituted-1,3-Thiazole Derivatives: Synthesis, Anti-Candida Activity Evaluation and Interaction with Bovine Serum Albumine. Molecules 2020, 25, 1079, https://doi.org/10.3390/molecules25051079.

25. Kaddouri, Y.; Abrigach, F.; Yousfi, E. B.; Kodadi, M. E.; Touzani, R. New thiazole, pyridine and pyrazole derivatives as antioxidant candidates: synthesis, DFT calculations and molecular docking study. Heliyon 2020, 6, e03185, https://doi.org/10.1016/j.heliyon. 2020.e03185.

26. Sahin, Z.; Biltekin, S. N.; Yurttas, L.; Demirayak, S. Synthesis, antioxidant and antimicrobial properties of novel pyridyl-carbonyl thiazoles as dendrodoine analogs. Turk J Chem 2020, 44, 1733-1741, https://doi:10.3906/kim-2008-8.

27. Raut, D. G.; Patil, S. B.; Choudhari, P. B.; Kadu, V. D.; Lawand, A. S.; Hublikar, M. G.; Bhosale, R. B. $\mathrm{POCl}_{3}$ Mediated Syntheses, Pharmacological Evaluation and Molecular Docking Studies of Some Novel Benzofused Thiazole Derivatives as a Potential Antioxidant and Anti-inflammatory Agents. 2020, 14, 58-68, https://doi.org/10.5772/intechopen.

28. Nikhila, G. R.; Batakurki, S. R.; Yallur, B. C. Synthesis, characterization and antioxidant studies of benzo[4, 5]imidazo[2, 1-b]thiazole derivatives. AIP Conference Proceedings 2020, 2274, 050017 , https://doi.org/10.1063/5.0023101.

29. Hossan, A. S. M. Synthesis, modelling and molecular docking of new 5-arylazo-2-chloroacetamido thiazole derivatives as antioxidant agent. J. Mol. Struct. 2020, 1206, 127712, https://doi.org/10.1016/j.molstruc.2020.127712.

30. Muluk, M. B.; Patil, P. S.; Kasare, S. L.; Kulkarni, R. S.; Dixit, P. P.; Choudhari, P. B.; Haval, K. P. Synthesis and molecular docking studies of novel pyridine-thiazole-hydrazone conjugates as antimicrobial and antioxidant agents. Eur. Chem. Bull. 2020, 9, 184-192, http://dx.doi.org/10.17628/ecb.2020.9.184-192.

31. Ramalingam, A.; Sarvanan, J. Synthesis, Docking and Anti-cancerous Activity of Some Novel Thiazole Derivatives of Biological Interest. Int. J. Pharm. Investigation 2020, 10, 594-603, http://www.jpionline.org/index.php/ijpi/article/view/815/520.

32. Bobade, V. D.; Pardeshi, S. Synthesis and biological evaluation of some novel triazol-3-ones as antimicrobial agents. Bioorg Med. Chem. Lett. 2011, 21, 6559-6562, https://doi.org/ 10.1016/j.bmcl.2011.08.049.

33. Sharifzadeh, B.; Mahmoodi, N. O.; Mamaghani, M.; Tabatabaeian, K.; Chirani, A. S.; Nikokar, I. Facile regioselective synthesis of novel bioactive thiazolyl-pyrazoline derivatives via a three-component reaction and their antimicrobial activity. Bioorg Med Chem Lett. 2013, 23, 548-551, https://doi.org/10.1016/j.bmcl.2012.11.024.

34. Pawar, C. D.; Sarkate, A. P.; Karnik, K. S.; Bahekar, S. S.; Pansare, D. N.; Shelke, R. N.; Jawale, C. S.; Shinde, D. B. Synthesis and antimicrobial evaluation of novel ethyl 2-(2-(4-substituted)acetamido)-4- 
subtituted-thiazole-5-carboxylate derivatives. Bioorg Med Chem Lett. 2016, 26, 3525-3528, https://doi.org/10.1016/j.bmcl.2016.06.030.

35. Nural, Y.; Gemili, M.; Ulger, M.; Sari, H.; Coen, L. M. D.; Sahin, E. Synthesis, antimicrobial activity and acid dissociation constants of methyl 5,5-diphenyl-1-(thiazol-2-yl)pyrrolidine-2-carboxylate derivatives. Bioorg Med Chem Lett. 2018, 28, 942-946, https://doi.org /10.1016/j.bmcl.2018.01.045.

36. Metwally, N. H.; Abdalla, M. A.; Mosselhi, M. A. N.; EI-Desoky, E. A. Synthesis and antimicrobial activity of some new N-glycosides of 2-thioxo-4-thiazolidinone derivatives. Carbohydr. Res. 2010, 345, 1135-1141, https://doi.org/10.1016/j.carres.2010.04.011.

37. Desai, N.C.; Joshi, V. V.; Rajpara, K. M.; Vaghani H. V. Facile synthesis of novel fluorine containing pyrazole based thiazole derivatives and evaluation of antimicrobial activity. J. Fluor. Chem. 2012, 142, 6778, https://doi.org/10.1016/j.jfluchem.2012.06.021.

38. Desai, N. C.; Rajpara, K. M.; Joshi, V. V. Microwave induced synthesis of fluorobenzamides containing thiazole and thiazolidine as promising antimicrobial analogs. . J. Fluor. Chem. 2013, 145, 102-111, https://doi.org/10.1016/j.jfluchem.2012.10.012.

39. Guzeldemirci, N. U.; Kuçukbasmac1, O. Synthesis and antimicrobial activity evaluation of new 1,2,4-triazoles and 1,3,4-thiadiazoles bearing imidazo[2,1-b]thiazole moiety. Eur. J. Med. Chem 2010, 45, 63-68, https://doi.org/10.1016/j.ejmech.2009.09.024.

40. Gouda, M. A.; Berghot, M. A.; El-Ghani, G. E. A.; Khalil, A. M. Synthesis and antimicrobial activities of some new thiazole and pyrazole derivatives based on 4, 5, 6, 7-tetrahydrobenzothiophene moiety. Eur. J. Med. Chem 2010, 45, 1338-1345, https://doi.org/10.1016/j.ejmech.2009.12.020.

41. Sarojini B. K.; Krishna B. G.; Darshanraj, C. G.; Bharath, B. R.; Manjunatha, H. Synthesis, characterization, in vitro and molecular docking studies of new 2,5-dichloro thaienyl substituted thiazole derivatives for antimicrobial properties. Eur. J. Med. Chem 2010, 45, 3490-3496, https://doi.org/10.1016/j.ejmech.2010.03.039.

42. Shingate, B. B.; Hazra, B. G.; Salunke, D. B.; Pore, V. S.; Shirazi, F.; Deshpande, M. V. Stereo selective synthesis and antimicrobial activity of steroidal C-20 tertiary alcohols with thiazole/pyridine side chain. Eur. J. Med. Chem 2011, 46, 3681-3689, https://doi.org/10.1016/j.ejmech.2011.05.032.

43. Arshad, A.; Osman, H.; Bagley, M. C.; Lam, C. K.; Mohamad, S.; Zahariluddin, A. S. M. Synthesis and antimicrobial properties of some new thiazolyl coumarin derivatives. Eur. J. Med. Chem 2011, 46, 37883794, https://doi.org/10.1016/j.ejmech.2011.05.044.

44. Karuvalam, R. P.; Haridas, K. R.; Nayak, S. K.; Row, T. N. G; Rajeesh, P.; Rishikesan, R.; Kumari, N. S. Design, synthesis of some new (2-aminothiazol-4-yl)methylester derivatives as possible antimicrobial and antitubercular agents. Eur. J. Med. Chem 2012, 49, 172-182, https://doi.org/10.1016/j.ejmech.2012.01.008.

45. Bondock, S.; Naser, T.; Ammarb, Y. A. Synthesis of some new 2-(3-pyridyl)-4,5-disubstituted thiazoles as potent antimicrobial agents. Eur. J. Med. Chem 2013, 62, 270-279, https://doi.org/10.1016/j.ejmech.2012.12.050.

46. Desai, N. C.; Bhatt, N.; Somani, H.; Trivedi, A. Synthesis, antimicrobial and cytotoxic activities of some novel thiazole clubbed 1, 3, 4-oxadiazoles Eur. J. Med. Chem 2013, 67, 54-59, https://doi.org/10.1016/j.ejmech.2013.06.029.

47. Zablotskaya, A.; Segal, I.; Geronikaki, A.; Eremkina, T.; Belyakov, S.; Petrova, M.; Shestakova, I.; Zvejniece, L.; Nikolajeva, V. Synthesis, physicochemical characterization, cytotoxicity, antimicrobial, antiinflammatory and psychotropic activity of new N-[1,3-(benzo)thiazol-2-yl]-u-[3,4-dihydroisoquinolin2(1H)-yl] alkanamides. Eur. J. Med. Chem 2013, 70, 846-856, https://doi.org/10.1016/j.ejmech.2013.10.008.

48. Rostom, S. A. F.; Faidallah, H. M.; Radwan, M. F.; Badr, M. H. Bifunctional ethyl 2-amino-4-methylthiazole5-carboxylate derivatives: Synthesis and in vitro biological evaluation as antimicrobial and anticancer agents. Eur. J. Med. Chem 2014, 76, 170-181, https://doi.org/10.1016/j.ejmech.2014.02.027.

49. Reddy, G. M.; Garcia, J. R.; Reddy, V. H.; Andrade, A. M. de.; Jr, A. C.; Ribeiro, R. A. P.; Lazaro, S. R. de. Synthesis, antimicrobial activity and advances in structure-activity relationships (SARs) of novel trisubstituted thiazole derivatives. Eur. J. Med. Chem 2016, 123, 508-513, https://doi.org/10.1016/j.ejmech.2016.07.062.

50. El-Wahab, H. A.; El-Fattah, M. A; El-Khalik, N. A, Nassar, H. S.; Abdelall, M. M. Synthesis and characterization of coumarin thiazole derivative2-(2-amino-1,3-thiazol-4-yl)-3H-benzo[f]chromen-3-one with antimicrobial activity and its potential application in antimicrobial polyurethane coating. Prog. Org. Coat. 2014, 77, 1506-1511, https://doi.org/ 10.1016/j.porgcoat.2014.04.026. 
51. Liaras, K.; Geronikaki, A.; Glamoclija, J.; Ciric, A.; Sokovic, M. Thiazole-based chalcones as potent antimicrobial agents. Synthesis and biological evaluation. Bioorg. Med. Chem 2011, 19, 3135-3140, https://doi.org/10.1016/j.bmc.2011.04.007.

52. Shah, N. K.; Shah, N. M.; Patel, M. P.; Patel, R. G. Synthesis, characterization and antimicrobial activity of some new biquinoline derivatives containing a thiazole moiety. Chin. Chem. Lett. 2012, 23, 454-457, https://doi.org/10.1016/j.cclet.2012.01.042.

53. Jagani, C. L.; Sojitra, N. A; Vanparia, S. F.; Patel, T. S.; Dixit, R. B.; Dixit, B. C. Microwave promoted synthesis and antimicrobial activity of 3-thiazole substituted 2-styryl-4(3H)-quinazolinone derivatives. $J$. Saudi Chem. Soc. 2012, 16, 363-369, https://doi.org/10. 1016/j.jscs.2011.02.001.

54. Desai, N. C.; Makwana, A. H.; Rajpara, K. M. Synthesis and study of 1,3,5-triazine based thiazole derivatives as antimicrobial agents. J. Saudi Chem. Soc. 2016, 20, S334-S341, https://doi.org/10.1016/j.jscs.2012.12.004.

55. Bikobo, D. S. N.; Vodnar, D. C.; Stana, A.; Tiperciuc, B.; Nastasa, C.; Douchet, M.; Oniga, O. Synthesis of 2-phenylamino-thiazole derivatives as antimicrobial agents. J. Saudi Chem. Soc. 2017, 21, 861-868, http://dx.doi.org/10.1016/j.jscs.2017.04.007.

56. Etaiw, S. E. H.; El-Aziz, D. M. A; El-Zaher, E. H. A; Ali, E. A. Synthesis, spectral, antimicrobial and antitumor assessment of Schiff base derived from 2-aminobenzothiazole and its transition metal complexes. Spectrochim. Acta A 2011, 79, 1331-1337, https://doi.org/10.1016/j.saa.2011.04.064.

57. Abdellatif, K. R. A.; Wareth, G. A. A. E.; EI-Badry, O. M.; Ragad, H. M.; EI-Enany, M. M. Synthesis and antimicrobial evaluation of certain purine, benzothiazole and thiazole systems substituted with dialkylaminoalkyl-o-cresols. Beni-Suef uni. j basic appl. sci-beni. 2015, 4, 52-59, https://doi.org/10.1016/j.bjbas.2015.02.008.

58. Aliamali, N. M.; Jwad, S. M.; Jouid, Z. M.; Ali, S. K. Microbial Studying of (thiazole, oxadiazole, thiadiazole)-Derivatives on mouth and teeth Bacteria. Int. J. Pharm. Biomed. sci 2016, 3, 30-39, https://doi.org/10.5281/zenodo.61357.

59. Karki, R.; Rao, G. K.; Gupta, A.; Mariappan, G.; Adhikari, S. Synthesis, Characterization and Antimicrobial Activities of Schiff bases of 2-amino-4-(O-chloroanilino)-1, 3-thiazole. J Appl Pharm Sci 2013, 3, 93-96, https://doi.org/10.7324/JAPS.2013.3717.

60. Arora, P.; Narang, R.; Bhatia, S.; Nayak, S. K.; Singh, S. K.; Narasimhan, B. Synthesis, molecular docking and QSAR studies of 2, 4-disubstituted thiazoles as antimicrobial agents. J Appl Pharm Sci 2015, 5, 28-42, https://doi.org/10.7324/JAPS.2015.50206.

61. Bhuiyan, M. H.; Rahman, A. F. M. H. Synthesis and Antimicrobial Evaluation of Some Thiazole Derivatives. J Sci Res 2010, 3, 111-119, https://doi.org/10.3329/jsr.v3i1.5419.

62. Ameta, C.; Sitha, D.; Ameta, R., Ameta, S. C. Synthesis and Antimicrobial Activity of Thiazole derivatives containing Triazole moiety using $\mathrm{LiBr}$ as a catalyst. Indones. J. Chem. 2010, 10, 376-381, https://doi.org/10.22146/ijc.21446.

63. Mohamed, H. A.; Abdel-Latif, E.; Abdel-Wahab, B. F.; Awad, G. E. A. Novel Antimicrobial Agents: Fluorinated 2-(3-(Benzofuran-2-yl)pyrazol-1-yl)thiazoles. Int $J$ Med Chem 2013, 1-6, http://dx.doi.org/10.1155/2013/986536.

64. Abhale1, Y. K.; Shinde, A.; Deshmukh, K. K.; Nawale, L.; Sarkar, D.; Mhaske, P. C. Synthesis, antitubercular and antimicrobial potential of some new thiazole substituted thiosemicarbazide derivatives. Med Chem Res 2017, 26, 2557-2567, https://doi.org/ 10.1007 /s00044-017-1955-1.

65. Al-Mousawia, S. M.; Moustafa, M. S.; Al-Saleh, E. Antimicrobial Activities of Some Novel Thiazoles. Russ J Bioorg Chem 2016, 42, 428-433, https://doi.org/10.1134/S1068162016040038.

66. Ansari, M. I.; Khan, S. A. Synthesis and antimicrobial activity of some novel quinolinepyrazoline based coumarinyl thiazole derivatives. Med Chem Res 2017, 26, 1481-1496, https://doi.org/10.1007/s00044-0171855-4.

67. Sreedevi, M.; Prasad, A. R. G.; Spoorthy, Y. N.; Rao, L.; Ravindranath, K. R. Synthesis and Antimicrobial Evaluation of Certain Novel Thiazoles. Adv Pharm Bull 2013, 3, 227-230, http://dx.doi.org /10.5681/apb.2013.037.

68. Oniga, S.; Duma, M.; Oniga, O.; Tiperciuc, B.; Pirnau, A.; Araniciu, C.; Palage, M. Synthesis of some new 4-methyl-2-(4-pyridyl)-thiazole-5-yl-azoles as potential antimicrobial agents. Farmacia 2015, 63, 171-178, http://www.revistafarmacia.ro/201502/art-02-Oniga_171-178.pdf. 
69. Asundaria, S. T.; Patel, K.C. Synthesis, characterization and antimicrobial activity of thiazole, benzothiazole and pyrimidine derivatives bearing sydnone moieties. Pharm Chem J 2012, 45, 725-731, https://doi.org/10.1007/s11094-012-0712-5.

70. Salem, M. A. Synthesis of New Thiazole, Bithiazolidinone and Pyrrano[2,3-d]thiazole Derivatives as Potential Antimicrobial Agents. Croat. Chem. Acta 2017, 90, 1-9, https://doi.org/10.5562/cca2955.

71. Chidananda, N.; Poojary, B.; Sumangala, V.; Kumari, N. S. Unnikrishna. Hantzsch and Schiff's reaction: synthesis, in vitro cytotoxic and antimicrobial activity of [1,3,4]oxadiazoline and [1,3]thiazole derivatives. Med Chem Res 2014, 23, 3979-3997, https://doi.org/10.1007/s00044-014-0975-3.

72. Hady, H. A. E. Syntheses and antimicrobial activity of some new thiohydantoin and thiazole derivatives. Der. Pharma. Chemica 2012, 4, 2202-2207.

73. Desai, N. C.; Bhatt, N.; Somani, H. Synthesis, characterization, and antimicrobial activity of some novel thiazole clubbed 1,3,4-oxadiazoles. Med Chem Res 2015, 24, 258-266, https://doi.org/10.1007/s00044-0141108-8.

74. Desai, N. C.; Shilroy, N.; Kiran, R.; Dodiya, A. Synthesis, characterisation and antimicrobial screening of novel quinolone-thiazole derivative. Indian J. Chem. 2012, 51b. 508-513, http://nopr.niscair.res.in/handle/123456789/13697.

75. Desai, N. C.; Joshi, V. V.; Rajpara, K. M.; Vaghani, H. V.; Satodiya, H. M. Synthesis of quinolone-oyrazoline based thiazole derivative endowed with antimicrobial activity. Indian J. Chem. 2013, 52b, 1191-1201, http://nopr.niscair.res.in/handle/123456789/21114.

76. Kheder, N. A.; MabkhotInt, Y. N. Synthesis and Antimicrobial Studies of Some Novel Bis-[1,3,4]thiadiazole and Bis-thiazole Pendant to Thieno[2,3-b]thiophene Moiety. Int. J. Mol. Sci. 2012, 13, 3661-3670, https://doi.org/10.3390/ijms13033661.

77. Desai, N. C.; Rajapara, K. M.; Joshi, V. V.; Vaghani, H. V.; Satodiya, H. M. Synthesis and Characterization of Some New Thiazole based Thiazolidinone Derivatives as Potent Antimicrobial and Antimycobacterial Agents. Anti-Infective Agents 2012, 10, 75-86.

78. Mahmoodi, N. O.; Khalili, B.; Rezaeianzade, O.; Ghavidast, A. One-pot multicomponent synthesis of indol3-ylhydrazinyl thiazoles as antimicrobial agents. Res Chem Intermed 2016,42, 6531-6542, https://doi.org/10.1007/s11164-016-2478-y.

79. Sadek, B.; Al-Tabakha, M. M.; Fahelelbom, K. M. S. Antimicrobial Prospect of Newly Synthesized 1,3Thiazole Derivatives. Molecules 2011, 16, 9386-9396, https://doi.org/10.3390/molecules16119386.

80. Nastasa, C.; Tiperciuc, B.; Duma, M.; Benedec, D.; Oniga, O. New Hydrazones Bearing Thiazole Scaffold: Synthesis, Characterization, Antimicrobial, and Antioxidant Investigation. Molecules 2015, 20, 1732517338; https://doi.org/10.3390/molecules200917325.

81. Gaffer, H. E.; Fouda M. M. G.; Khalifa, M. E. Synthesis of Some Novel 2-Amino-5-arylazothiazole Disperse Dyes for Dyeing Polyester Fabrics and Their Antimicrobial Activity. Molecules 2016, 21, 122, https://doi.org/10.3390/molecules21010122.

82. Singh, N.; Sharma, U. S.; Sutar, N.; Kumar, S.; Sharma, U. K. J. Synthesis and antimicrobial activity of some novel 2-amino thiazole derivatives. Chem Pharm Res 2010, 2, 691-698.

83. Parekh, N. M.; Juddhawala, K. V.; Rawal, B. M. Antimicrobial activity of thiazolyl benzenesulfonamidecondensed 2,4-thiazolidinediones derivatives. Med Chem Res 2013, 22, 2737-2745, https://doi.org/10.1007/s00044-012-0273-X.

84. Praveen, A. S.; Yathirajan, H. S.; Narayana, B.; Sarojini, B. K. Synthesis, characterization and antimicrobial studies of a few novel thiazole derivatives. Med Chem Res 2014, 23, 259-268, https://doi.org/10.1007/s00044013-0629-X.

85. Yurttas, L.; Ozkay, Y.; Kaplancıkl1, Z. A.; Tunalı, Y.; Karaca, H. Synthesis and antimicrobial activity of some new hydrazone-bridged thiazole-pyrrole derivatives. J Enzyme Inhib Med Chem 2013, 28, 830-835, https://doi.org/10.3109/14756366.2012.688043.

86. Dawane, B. S.; Konda, S. G.; Shaikh, B. M., Chobe, S. S.; Khandare, N. T.; Kamble, V. T.; Bhosale, R. B. Synthesis and in vitro antimicrobial activity of some new 1-thiazolyl-2-pyrazoline derivatives. Int J Pharm Sci Rev Res 2010, 1, 144-148.

87. Sadek, B.; Al-Tabakha, M. M. Anti-microbial Prospect of Newly Synthesized 1,3-Thiazole Derivatives. Molecule 2011, 16, 9386-939, https://doi.org/10.3390/molecules16119386. 
88. Yadlapalli, R. K.; Chourasia, O. P.; Jogi, M. P.; Podile, A. R.; Perali, R. S. Design, synthesis and in vitro antimicrobial activity of novel phenylbenzamido-aminothiazole-based azasterol mimics. Med Chem Res 2013, 22, 2975-2983, https://doi.org/10.1007/s00044-012-0314-5.

89. Zablotskaya, A.; Segal, I.; Geronikaki, A.; Kazachonokh, G.; Popelis, Y.; Shestakova, I.; Nikolajeva, V.; Eze, D. Synthesis and biological evaluation of lipid-like 5-IJ2-hydroxyethyl)-4-methyl-1,3-thiazole derivatives as potential anticancer and antimicrobial agents. Med Chem Commun 2015, 6, 1464-1470, https://doi.org/10.1039/C5MD00140D. 